\title{
Knowledge and Perceptions of Students with Disabilities in Regard to a Resource Room in a Private School
}

Susan C. Blackford

Cedarville University

Follow this and additional works at: http://digitalcommons.cedarville.edu/education_theses

Part of the Special Education and Teaching Commons

\section{Recommended Citation}

Blackford, Susan C., "Knowledge and Perceptions of Students with Disabilities in Regard to a Resource Room in a Private School" (2010). Master of Education Research Theses. 25.

http://digitalcommons.cedarville.edu/education_theses/25 


\title{
KNOWLEDGE AND PERCEPTIONS OF STUDENTS WITH DISABLITIES IN REGARD TO A RESOURCE ROOM IN A PRIVATE SCHOOL
}

\author{
A thesis submitted in partial fulfillment \\ of the requirements for the degree of \\ Masters of Education
}

By

SUSAN CAROL BLACKFORD

B. A. Elementary Education, Cedarville University, 2003

2010

Cedarville University 


\section{CEDARVILLE UNIVERSITY \\ SCHOOL OF GRADUATE STUDIES}

August 1, 2010

I HEREBY RECOMMEND THAT THE THESIS PREPARED UNDER MY SUPERVISION BY Susan Carol Blackford ENTITLED Knowledge and Perceptions of Students with Disabilities in Regard to a Resource Room in a Private School BE ACCEPTED IN PARTIAL FULFILLMENT OF THE REQUIREMENTS FOR THE DEGREE OF Master of Education.
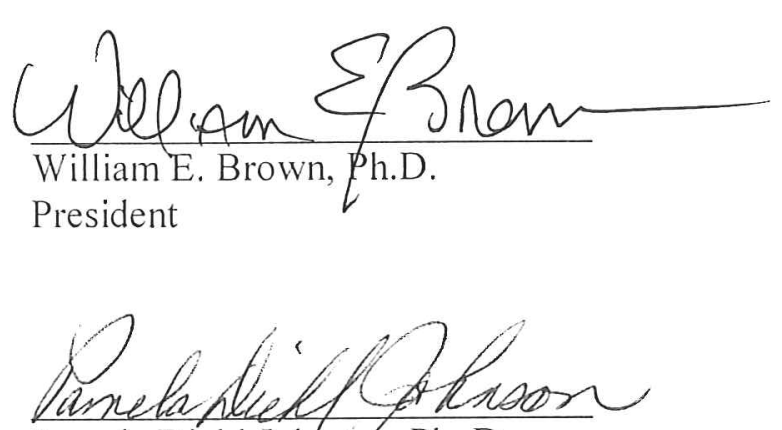

Pamela Diehl Johnson, Ph. D. Dean, School of Social Sciences and Human Performance

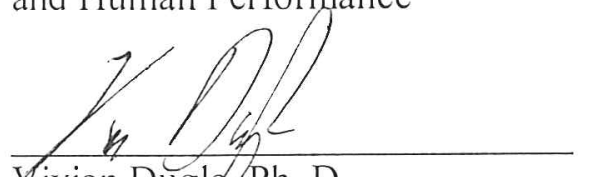

Vivian Dugle, Ph. D.

Thesis Adyrsor

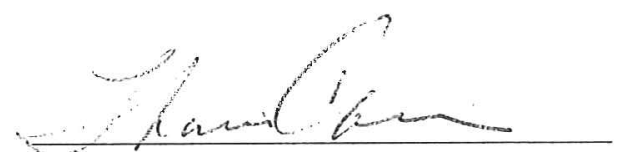

Thomas Cornman, Ph. D. Academic Vice President

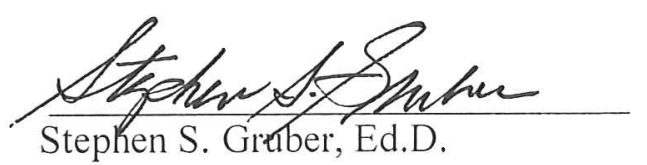
Education Department Chair Director M.Ed. Program

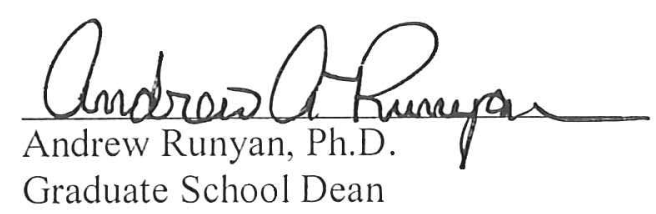




\begin{abstract}
Blackford, Susan C. M.Ed., Education Department, Cedarville University, 2010. Knowledge and Perceptions of Students with Disabilities in Regard to a Resource Room in a Private School.
\end{abstract}

This qualitative study focused on student knowledge and perceptions of the resource room in a private school. Students on an IEP or eligible for an IEP and that had attended the resource room were interviewed on the five constructs: knowledge, perceptions, benefits, limitations, and suggestions for improvement. Teachers and administrators were surveyed regarding these same five constructs. This study represents a small private K-12 school of approximately 170 students where the main service model is the resource room. Analysis of the results revealed that students perceived the resource room teacher, the ability to receive help and the quiet atmosphere as benefits of the resource room. Limitations and suggestions for improvement are also included. These results can be used to effectively structure the resource room to best meet the needs of students with disabilities. 


\section{TABLE OF CONTENTS}

CHAPTER I: Introduction...................................................

Definition of Terms................................................... 5

Statement of Issue...................................................6

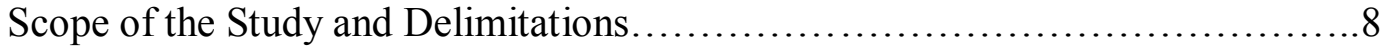

Significance of the Study..........................................

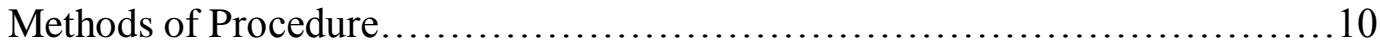

CHAPTER II: Plenary Literature Review...................................13

Labeling ........................................................ 13

History of Special Education........................................ 14

Types of Service and Placement Options............................... 18

Self-Concept and Placement........................................27

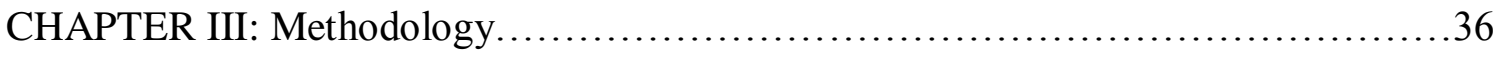

Rationale for the Method............................................... 37

Population of the Study............................................. 37

Sample......................................................... 38

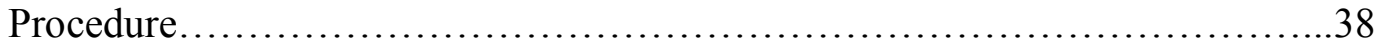

CHAPTER IV: Qualitative Analysis........................................43

Description of the Data.............................................44

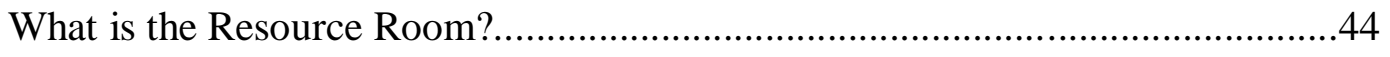

Why Do You Think You Come to the Resource Room?..................................47 
Benefits of the Resource Room..........................................52

Limitations of the Resource Room.....................................56

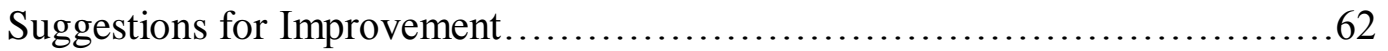

Summary......................................................66

CHAPTER V: Discussion and Implications...................................68

Interpretation of the Results..........................................68

Potential Applications of the Findings.................................. 79

Biblical Integration................................................... 87

Relation of Results to Literature..................................... 89

Strengths of Study................................................ 92

Limitations of Study............................................ 94

Suggestions for Future Research...................................... 96



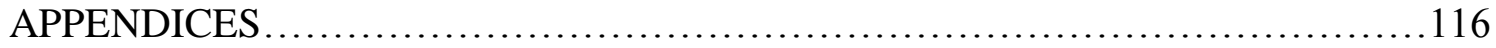

APPENDIX A: Interview and Survey Questions..........................116

APPENDIX B: Parental and Student Consent Form.......................117

APPENDIX C: Teacher and Administrator Consent Form...................119 


\section{ACKNOWLEDGEMENTS}

Thank you to my precious Lord and Savior for His unspeakable gifts. He has granted me the wisdom to complete this project and the desire to be a Master teacher.

I would like to thank my husband, parents and faithful family and friends for their prayer support and continual encouragement. My husband has patiently and lovingly stood beside me through this long journey. My parents have willingly sacrificed much throughout the years so that I could have a godly education. My family and friends cheered and encouraged me from the sidelines. Together they have inspired me to work harder, reach higher and never give up.

I would like to thank the wonderful students, parents, staff and administrators at Christian Academy Schools for their willingness to participate in this study and their eagerness to share with me. Thank you for your time, flexibility and patience. You are a blessing. 


\section{Chapter 1}

\section{Introduction}

Historically educators have faced the challenging demand to ensure no child is left behind. As a result general classrooms are replete with students of various and differing learning abilities. Public Law 94-142 seeks to ensure that all students receive an appropriate education (Vaughn, Elbaum, \& Boardman, 2001). Various service models and placements have been developed as mandated by law. Policymakers, educators and advocates have argued and debated over the best placement, yet the voices of most students with disabilities remain silent. Educators would be wise to understand student perspectives and educational views before undergoing educational policy and reform (Vaughn \& Klingner, 1998).

Wamba (2008) acknowledges that as early as 1880 school reformers were actively aware of the different learning needs of students. However, much of the legislation concerning disabilities is wrapped up in recent laws. P. L. 94-142, IDEA and IDEA 2004 comprise the major laws requiring students with disabilities be placed in the least restrictive environment, receiving equal access to the general curriculum (Wamba, 2008). Although there are specific mandates in the law, the law does not delineate between various service models or give preference to any of them. The best placement model for students with disabilities has often been the decision of parents and educators. 
Prior to P. L. 94-142 the majority of students with sensory, physical and cognitive disabilities were educated in separate facilities (Winzer, 1993). However, students with learning disabilities received most of their instruction in the regular classroom without consideration to their specific learning needs (Vaughn et al., 2001). P. L. 94-142 was passed to address the issues and concerns of parents and advocates. The resource room developed as the primary model for servicing students with disabilities under the least restrictive environment mandate (Kavale \& Forness, 2000).

Students with disabilities can be placed in a variety of service settings along a continuum. Placements depend upon the severity of disabilities and the specific needs of the student. Deno (1970) and Reynolds (1962) developed various placement options known as the cascade-of-services model. Services range from the general classroom as the most inclusive to a hospital or residential placement as the least inclusive. Services in between may place students in a general classroom with consultative assistance, part-time resource room or part-time special class. Students with more severe disabilities may be placed in a full time special class, day school or even limited to instruction at home. The most common placements for students with mild disabilities range from the general classroom to support services in addition to the regular classroom.

At the forefront of the placement debate is the effectiveness of each program and the social and emotional impact on students. Wiener and Tardif (2004) note that even recent studies still have not resolved the placement controversy. The recent push toward inclusion has both proponents and opponents. Sacks (2001) lists three hopes of mainstreaming students: an increase in social interaction, social acceptance and appropriate behavior. Vaughn et al. (2001) advocates that students with learning 
disabilities in a less restrictive setting have a more positive school experience in regard to self-perception, acceptance and peers. Elbaum (2002) argues that the greater the degree of separation, the greater the potential is for negative stigma.

According to Vaughn and Bos (1987) the resource room functions as one of the primary models of special education. The special education teacher is considered the expert in the resource room for students with mild disabilities (Manset \& Semmel, 1997). However, much of the literature regarding the resource room is significantly outdated. Jenkins and Heinen (1989) found that many students both with and without disabilities preferred the resource model rather than other service models. Shoho, Katims, and Wilks (1997) reported that students with learning disabilities serviced in a resource room felt less in control of the learning environment than those in an inclusive setting and their value structure was not as consistent as their peers. In comparing resource rooms to inclusion, Whinnery and King (1995) assert that students with learning disabilities in resource rooms tend to feel dumb, made fun of, left out and embarrassed more often than students in inclusive settings. In contrast Vaughn and Klingner (1998) cite four positive reasons that students enjoy the resource room. Students prefer the resource room due to the additional help, exciting activities, lessened work load, and the ability to work in a quiet setting. Weiner and Tardif (2004) found that resource room students were not accepted by peers as well as inclusion students were. Elbaum (2002) asserts that no difference in self-concept was found in comparison of students with learning disabilities in resource rooms and inclusive settings and argued that the association between selfconcept and placement was not supported. In the controversy of placement, students do not always agree on which is the best. Vaughn and Klingner (1998) discovered that 
students with learning disabilities do not prefer one model to another. Previous literature reveals inconsistencies and incongruities.

Lower self-concept and stigmatization of students with learning disabilities is fundamental to the arguments and research on placement. In depth studies have revealed that students with learning disabilities often have lower self-perceptions regarding intellect and academics than students without learning disabilities (Bear, Minke, \& Manning, 2002). Gans, Kenny, and Ghany (2003) report that the self-concept of students with learning disabilities is also significantly lower than their peers without learning disabilities. Vaughn and Hogan (1990) note that a positive self-concept is imperative to social competence. In general, students with learning disabilities exhibit lower selfperceptions, which could lead to lower social competence.

However, despite lower self-concept, several studies have researched the global self-esteem of students with learning disabilities and found it to be equal to that of students without disabilities (Bear et al., 2002; Gans et al., 2003). Often students report a lower self-concept in an academic area but maintain the same level of global self-concept as their peers (Gans et al., 2003). Conley, Ghavami, VonOhlen \& Foulkes, 2007 conclude that students with learning disabilities do not feel worthless. They recognize they have greater strengths in other areas. As a result global self-concept may remain on an equal level to that of their peers.

Although placement effectiveness has been a much researched subject, few studies have attempted to address the perspectives of students with disabilities in regard to their knowledge and perceptions of the educational process and placement. Students need room to explain their experiences and perceptions. Little research has fully 
penetrated student perceptions and knowledge of the resource room (Vaughn \& Bos, 1987). From the 1990's to the present much of the literature on the resource room is silent. Two qualitative studies sought to delve into perceptions and attitudes of students with learning disabilities in resource rooms. Both studies interviewed students to gain an inside, in-depth understanding. Vaughn and Bos (1987) questioned students regarding knowledge and the definition of special education and the resource room. Significant findings as well as implications were included. Albinger (1995) descriptively wrote findings portraying the life of students in a resource classroom. Rich in personal student narratives and descriptions, Albinger retells the stories of those she interviewed noting overarching themes. Both past and present studies leave a stark void of knowledge regarding student perceptions of the resource room.

\section{Definition of Terms}

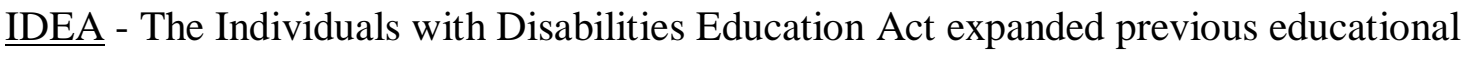
programs, required consideration of assistive technology and specifically provided students with disabilities access to the general curriculum (Wamba, 2008).

IDEA 2004- IDEA 2004 is often referred to as IDEIA, a federal legislation reauthorizing IDEA with revisions for determining a specific learning disability (Wamba, 2008).

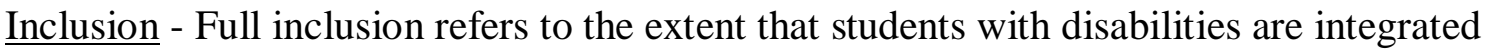
into the general classroom for the entire day and serviced by both general and special education teachers (Wiener \& Tardif, 2004).

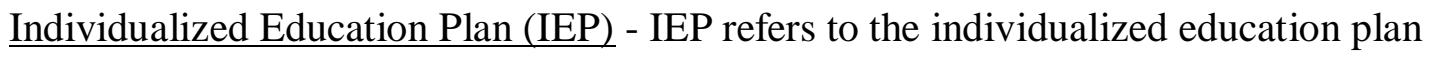
required for students with disabilities. An IEP includes an instructional plan for the child, present educational performance, and services needed (Vergason \& Anderegg, 1997). 
Learning Disability - A learning disability is defined as a discrepancy in performance and intellectual ability (McCoach, Kehle, Bray, \& Siegle, 2001). Students have a discrepancy between actual learning and a potential to learn (Conley et al., 2007).

Least Restrictive Environment (LRE) - LRE is a fundamental principle of IDEA that mandates that students with disabilities be educated with their peers to the maximum extent appropriately possible (Etscheidt, 2006).

Mainstreaming - Mainstreaming is an older term referencing students with disabilities that are placed in the general classroom as the least restrictive environment. Students may be in the general classroom for all or part of the day (Sacks, 2001).

Mild disabilities - Mild disabilities include learning disabilities, mild mental disabilities, emotional disabilities or behavioral disabilities and attention deficit hyper activity disorder. Mild disabilities can also be called high incidence disabilities and represent 2/3 of all students with disabilities (“High Incidence Disabilities,” 2006).

P. L. 94-142 - P. L. $94-142$ is the federal law that mandated free appropriate education in the least restrictive environment (Vaughn et al., 2001).

Resource Room - A resource room is defined as a separate class in which students with disabilities spend a small portion of their day receiving services. Students receive most of their education in the regular classroom and are pulled out as appropriate (Wiener \& Tardif, 2004).

\section{Statement of Issue}

Federal law mandates that educators meet the needs of students with disabilities. Disagreements over the best placement model have produced insignificant grounds for determining which one is most appropriate. Educators, policymakers and parents have 
devoted their lives to meeting the needs of students with disabilities, yet student knowledge and perceptions have largely been ignored. Researchers have studied student placement preference, yet little consideration has been given to their stories. Studies by Albinger (1995) and Vaughn \& Bos (1987) give voice to students with learning disabilities in a resource room, allowing them to share their perceptions and experiences. There is an increasing demand for student voices, perceptions, attitudes and knowledge regarding placement to be acknowledged and analyzed. Students are a crucial link in determining the most appropriate placement to meet their educational needs. Focused studies of placement are a necessary component to achieving this end.

The resource room is significant despite the scrutiny of its effectiveness or the silence of the literature. Little research has been devoted to studying students with disabilities in a private setting and even less in the area of the resource room. Eigenbrood (2005) studied the resource room and compared faith-based schools and public schools. The majority of research done on mild disabilities focuses on learning disabilities. Learning disabilities are the largest group of mild disabilities (Lerner, 1997). Vaughn \& Bos (1987) adequately argue that unless research into the perceptions and knowledge of the resource room is undertaken, one will never be able to fully understand how this influences student perceptions and attitudes regarding this model. One cannot appropriately analyze attitudes of the resource room without first understanding what a child knows about it. In order for the resource room to be an effective model, students' knowledge and perceptions must be given foremost consideration. 
Scope of the Study and Delimitations

In this study I collected data on student knowledge, perceptions, perceived benefits and limitations of the resource room and suggestions for improvement. Student experiences, input and positive feedback were encouraged and analyzed. The study was an action research project performed in a small private school with an enrollment of approximately 170 students (K-12) with a resource room as the main service delivery model. The student population was comprised of 93\% Caucasian, 5\% Multi-Racial, $1 \%$ Black and 1\% Asian/Pacific Islander. Historically, both students with IEPs and students without an IEP have been serviced in the resource room. However, this year only students with IEPs were serviced in the resource room. Five students from the elementary and five students from junior high and high school were interviewed. Three elementary students were girls and two were boys. Two of the junior high and high school students were girls and three were boys. One high school boy did not receive services in the resource room this year, but he had received services in the past. Similarly, data on the administration, educators and the special education teacher was collected. First through twelfth grade teachers were surveyed as well as part-time teachers in junior high and high school. The kindergarten teacher did not participate since she had not sent students to the resource room in a number of years. Three administrators and the special education teacher were also surveyed. The special education teacher has taught for ten years at the school. The scope of this study can be reasonably generalized to small private schools whose main service model is the resource room. 
This study did not analyze parent knowledge or perceived benefits and limitations of the resource room. Preferences or effectiveness of other service models was not assessed. Self-concept or global self-concept in regard to the resource room or other service models was not addressed. No determination was made toward recognizing academic gains in the resource room as it was not the purpose of this study.

Significance of Study

The educational needs of students with disabilities will always be a debate for politics and reform. Regardless of the service model a school uses, educators seek to meet the needs of their students to the maximum extent possible. It is crucial that educators are aware of the perceptions and knowledge students have regarding the service placement in their school. Jenkins and Heinen (1989) argue that it is dangerous to assume students see placements the way adults see them.

A service model is only as good as the students it services. Qualitative research describing the perceptions and knowledge of the resource room is limited. Studies by Vaugn \& Bos (1987) and Albinger (1995) on students with learning disabilities sought to portray student voices through their knowledge and perceptions of the resource room. It is imperative that educators understand how students with disabilities perceive the resource room. The experiences of the students with disabilities serve as a forum to assessing the effectiveness of the resource room in this particular setting. In many small private schools the only service model available is the resource room. This study will assist in closing the gap created by the void of literature. Limited research on the resource room in a private setting has been conducted. The potential to understand 
student views empowers educators to meet the needs of students with disabilities more effectively and exceed far beyond this study.

Limitations of the resource room can be effectively used to restructure the service model across generalized settings. Limitations must not exceed the benefits. Analyzing student perceptions and knowledge will give rise to student voices and enable students to become a part of the learning process. However, careful consideration must be given to ensure that student voices are heard in the proper place. Student perceptions, knowledge and attitudes must be balanced in light of the educational research regarding the resource room.

Student perceived benefits enable the educator to continue to improve and uphold the strengths of the program. Student perceived limitations provide valid and relevant feedback concerning improvements in the service delivery model. Students must acknowledge the value of the resource room in order for it to function properly.

Methods of Procedure

Research Questions:

1. What is the resource room and why do students perceive they go there?

2. What are the benefits of the resource room?

3. What are the limitations of the resource room?

4. What improvements could be made to the resource room?

This qualitative action research project was designed to examine the perceptions and knowledge of students with disabilities in regard to the resource room. The data was collected in the form of notes during the interviews as well as tape-recorded for further processing. Educators, administrators and the special education teacher were surveyed 
on their perceived knowledge, benefits, limitations and ideas for improvement in the resource room. Following an inductive approach, hypotheses were formed based on the analysis of the data. Data analysis included major themes regarding knowledge, benefits, limitations and suggestions for improvement.

Participants were required to meet the study's criteria. Students that attended the private school and received services in the resource room for less than $20 \%$ of the day were selected. Students meeting these criteria were mailed a letter indicating the purpose of the research study and asking for both parental and student consent. Parents were notified that students did not have to participate in the study and that they were welcome to drop out at any time without consequence. Parents reserve the right to review or delete any objectionable materials. Parents were informed that the interviews would be taped. Only participants with the proper criteria and parental and student consent were considered for participation in the study.

Based on criterion sampling, each student was interviewed for approximately 1015 minutes over the course of several weeks on the five constructs: knowledge, perceived benefits and limitations of the resource room and ideas for improvement. Students giving only cursory answers were encouraged to provide more in-depth answers after gentle probing. Younger students may have required slight wording change in the question in order to adequately portray their perceptions. All interviews were tape- recorded.

This qualitative study was inductive in nature. Analysis of the transcribed data included coding of major themes in the interviews. Themes that were not supported by the interviews were disregarded. Only the relevant themes evident in the interviews were 
reported and discussed. Implications for the resource room and further research were included. 


\section{Chapter Two}

\section{Plenary Literature Review}

The long history of special education in the United States is often cyclical and cynical in nature. For almost 200 years, parents, educators and policymakers have advocated for the educational rights of students with disabilities. Those educational rights were often fraught with delays, disappointments and discrimination. Only in recent years has significant progress been achieved. The study of special education history reveals past and present views and ideology, and provides insight into the future of special education.

\section{Labeling}

The common phrase "at risk" is almost 200 years old. Originally "at risk" referred to impoverished students facing academic failure and in need of assistance (Cuban, 1989). The terms "at risk" and "disabilities" have been used inconsistently throughout time. Handler (2007) asserts that, although federal guidelines for labeling disabilities are given, states sort and label students on their own. Furthermore, students do not have to meet clinical or psychiatric criteria before receiving a special education label, enabling educators to label students outside societal criteria. Today students with 
special education labels do not demonstrate the same disabilities as students from previous years. The actual testing of students for impairments has also drastically fallen (Individuals with Disabilities Education Improvement Act 2004).

The categorizing and labeling of students has created much confusion over the years. Two definitions of learning disabilities were present prior to P. L. 94-142 and provided the basis for the definition of learning disability in P. L. 94-142 (Handler, 2007). The definition shifted from stating that a student had a developmental delay (Kirk, 1962) to stating that the student showed a discrepancy between expected and actual achievement (Kass, 1971). P. L. 94-142 defines a learning disability as a discrepancy between actual and expected performance that is apparent through diagnostic testing (Handler, 2007). Although this definition might appear clear, it has been misused throughout its history, creating a difficulty in tracing special education history.

\section{History of Special Education}

Public education is not guaranteed under the Constitution. The tenth amendment delegates the responsibility of public education to the states (Yell, Rogers \& Lodge Rogers, 1998). As a result, differing ideology and treatments of students with disabilities has occurred throughout history. Prior to the end of the $19^{\text {th }}$ century, individuals with disabilities were largely ignored. A common practice of the 1870's was to educate students with disabilities in separate facilities. Special schools, day classes, basements and family homes were used to educate students with sensory, visual or cognitive impairments (Winzer, 1993). An increasing realization and concern for the needs of students with learning needs grew in the 1880's (Wamba, 2008). However, students with mild disabilities were educated in the general classroom. Their needs were not 
considered to be outstanding (Friend \& Bursuck, 2006; Vaughn \& Klingner, 1998). The first placement for students with blindness, deafness and orthopedic handicaps was not the general classroom. Instead justification for separation of students with severe disabilities stemmed from the assumption that they would fail and their pride would be diminished (Wamba, 2008). Sabatino (1979) reports that as early as 1875, Cleveland, Ohio, recorded the first use of a special self-contained class within the public school system for students with disabilities. By 1890, most major cities began using separate classes for students with disabilities. It became common and acceptable practice to segregate and isolate these students. National attention was focused on students with disabilities in the early $20^{\text {th }}$ century with the first White House Conference on Children in 1910 (Yell et al., 1998). This national focus shifted students with disabilities from isolation in institutions to segregating them within the public schools (Winzer, 1993).

The beginning of the $20^{\text {th }}$ century marked a new twist in educational law by mandating school attendance. By 1918, all states had mandatory education laws (Ysseldyke \& Algozzine, 1984). This did little to include students with disabilities in the regular classroom. Instead it gave further rise to separation. The underlying view of society was that schools were to be orderly and without disruptions (Handler, 2007). Despite the attendance laws, courts often upheld the exclusion of students with disabilities (Yell et al., 1998). As many as 5 million students with disabilities were still not attending public schools as late as 1940 (Winzer, 1993). Many of these students had severe disabilities. Students with disabilities were considered to be disruptions in the public educational system and justification for separation and exclusion was considered the norm. 
Change in ideology and views toward students with disabilities began in the middle of the $20^{\text {th }}$ century. The rights of students with disabilities began to take the forefront of national debate. In the 1920's and 1930's special classes were designed for students struggling to keep up (Friend \& Bursuck, 2006). According to Yell et al. (1998) the majority of states began passing laws requiring the education of students with disabilities in the 1960's and 1970's. Advocates used the precedent set with Brown v. Board of Education to argue that students with disabilities had the same rights, yet were being treated differently and were not given an education equal to that of students without disabilities (Yell et al., 1998). In addition the precedents set in Pennsylvania Association of Retarded Citizens (PARC) v. Commonwealth and Mills v. Board of Education were used to further argue against excluding students with disabilities, giving rise to P. L. 94142 (Gartner \& Lipsky, 1987). The idea of equal opportunity in education was not applied to students with disabilities until sixteen years after the Brown decision (Yell et al., 1998). It came after many years of discrimination and disappointment. The passage of Section 504 of the Vocational Rehabilitation Act of 1973 provided equal opportunity for students with disabilities in school functions (Smith, 2002). Students could receive some assistance even if they didn't qualify for special education (Friend \& Bursuck, 2006).

P. L. 94-142 is perhaps the most widely known law regarding special education. The Education for All Handicapped Children Act, also known as P. L. 94-142, was passed in 1975. At that time one million students with learning disabilities were excluded from public schools and over half did not receive services appropriate to their needs (Turnbull, Turnbull, Shank, Smith \& Leal, 2002). With the passage of P. L. 94- 
142, special education no longer fell under the power of the states but under federal power (Yell et al., 1998). Despite this major step, Handler (2007) notes that students with disabilities were no longer excluded from public education but neither were they included in public education. Separate education within the public school system was established as the common practice.

Many of the mandates for special education today are wrapped up in P. L. 94-142. P. L. 94-142 addressed individualized educational plans (IEPs) to service students with disabilities as well as established the least restrictive environment (LRE) (Wamba, 2008). The least restrictive environment mandate gave birth to the idea of mainstreaming (Kavale \& Forness, 2000). The idea of the least restrictive environment is still at the forefront of placement debate. However, as Wamba (2008) notes, initially the segregated location of students with learning disabilities did not cause alarm. Students were beginning to receive the services they desperately needed.

The Individuals with Disabilities Act (IDEA) was passed in 1990 as a reauthorization of P. L. 94-142 (Friend \& Bursuck, 2006). The name change was a result of a people first awareness effort (Turnbull et al., 2002). The word "disability" replaced the former word "handicapped" (Friend \& Bursuck, 2006). With the passage of IDEA came new changes to special education law. Free Appropriate Public Education (FAPE) became a mandate to all students with disabilities (Etscheidt, 2006). Etscheidt considers "appropriate" to be determined by benefits academically, non-academically or both. Appropriate education is determined on an individual basis by the needs of the child. In accordance of the law, schools were required to have a continuum of placement options for students with disabilities (Reynolds, 1962; Deno, 1970). The general 
classroom was merely an option but not a requirement for the least restrictive environment (Zirkel, 1996).

IDEA was reauthorized in 1997, extending to students with disabilities access to the general curriculum in the least restrictive environment (Wamba, 2008). It did not mandate inclusion. IDEA was reauthorized in 2004 and renamed Individuals with Disabilities Education Improvement Act (IDEIA) and included changes in the determination of a specific learning disability (Wamba, 2008). Today advocates and policy makers continue to fight for the rights of students with disabilities. It has been a long and difficult battle, but immense progress has been made.

\section{Types of Service and Placement Options}

Although students with disabilities have been allowed an equal education within the public system, the debate over the best placement still abounds. The purpose of special education is two-fold. First, the word "special" denotes an education different from general education (Zigmond \& Baker, 1995). It implies separate in either content, method or placement (McLaughlin, 1995). The purpose of special education is to meet the needs of students in the least restrictive environment by providing them with the necessary support, services, adaptations and accommodations (Skrtic, 1991). Therefore, a continuum of placement options for students with disabilities was created. Kauffman and Pullen (1996) argue that there is no "magic" placement. A placement is only as good as the instruction given and instruction is only effective if the proper number of students and the support available are appropriate. Kauffman and Pullen imply that, despite the location, without the support of general teachers, special education would fall apart. The main problem with placement is often schedules, available teachers and space (Sailor \& 
Roger, 2005). (Kauffman and Pullen (1996) assert that one assumes that being separate from the majority is always negative while being with the majority is always positive. It is this assumption that leads to the controversy over the best placement. Moore, Gilbreath and Maiuri (1998) further argue that special education refers to aids and services. It is not a placement.

The passing of P. L. 94-142 and the least restrictive environment mandate created the need for placement options. The terms mainstream, inclusion and resource room are not included in P. L. 94-142. The law required that a child be placed in the general classroom unless a specialized individual educational plan (IEP) otherwise noted a different placement (Shoho et al., 1997). The resource room developed as a response to P. L. 94-142's least restrictive environment mandate and became the primary placement model (Vaughn \& Bos, 1987; Kavale \& Forness, 2000). Students could be members of the general class but still receive specialized instruction. The first known resource room was created in 1963, in Iowa, while the majority of resource programs were started between 1970-1975 (Friend \& McNutt, 1984). Prior to 1984, the only categories for recording the educational setting were general classrooms or separate classrooms. The resource room was established in 1984, as a separate category (Handler, 2007).

Furthermore, the reporting of the educational setting changed in 1990, from the number of students in general and separate classes to the amount of time students spent outside the general classroom. Studies by Friend and McNutt (1984) revealed that 38 states used the term resource room. Eight states called their programs resource rooms or learning centers while five states did not use the term at all. The least restrictive environment mandate gave birth to the resource room as well as other placement options. 
In every placement model the collaboration between special education and regular classroom teachers varies. Idol (2006) explains four collaborative models: the consulting teacher model, cooperative teacher model, supportive resource programs and instructional assistants. In the consulting teacher model, the classroom teacher consults with the special education teacher and the students are serviced indirectly (Idol, Nevin \& Paolucci-Whitcomb, 1994, 2000). In this model, the general classroom teacher retains the responsibility for teaching the student with disabilities in the general classroom with some support indirectly from the special education teacher. Both general and special education teachers co-teach in the general classroom in the cooperative teacher model (Bauwens, Hourcade \& Friend, 1989). This model is supportive of an inclusive placement. The services are brought directly to the student in the general classroom. The resource room program is defined by Wiederholt and Chamberlain (1989) as a place where a child is able to receive general support but spends the majority of time in the classroom. It is not a part-time special education class, consultative program, study hall, or detention center. The purpose is to transfer learning from the resource room into the general classroom. In the final model, instructional assistants accommodate students with special needs the whole day within the general classroom acting as their personal assistant (Idol, 2006). This is also an example of an inclusive classroom. In each of these models the responsibility for teaching students with disabilities can be shared by teachers or lean heavily on only one teacher.

Resource rooms, mainstreaming and inclusion are familiar terms for placement options. Mainstreaming and inclusion are categorically different, whereas mainstreaming and resource rooms often go hand in hand. In mainstreaming, students with disabilities 
spend the majority of their day in the general classroom and a portion of their day in a special educational setting. This is most often the resource room (Idol, 1997; Smelter \& Rasch, 1994). In contrast, students with disabilities in the inclusive model are educated the entire day within the general classroom (Idol, 1997). In an inclusion placement the services (ie. special education teachers or instructional assistants) come directly to the student rather than the student going to the services (Smelter \& Rasch, 1994). Phillips, Sapona \& Lubic (1995) further clarify the difference between inclusion and mainstreaming. Mainstreaming attempts to fit the student with disabilities in the general environment by transferring skills learned in the resource room. In the inclusive classroom, the environment is organized to fit the needs of the student with disabilities. The current educational trend is toward full inclusion, although many public schools still use mainstreaming and resource rooms to service their students.

The popularity of the inclusion model may lie within its purpose. The heart of inclusion is the desire to meet the needs of every student, while teaching students to appreciate and learn from differences (Salend, 1998; Zorfass, 1994). A study by Swick and Hooks (2005) outlined four main reasons why parents choose inclusive classrooms. Parents wanted to be a part of their child's learning as well as see their child live as regular a life as possible. Parents chose inclusive classrooms because they believed that a separate classroom socially and academically limited their child. Other advocates suggest that children learn best in the general classroom and that pull out programs such as resource rooms violate civil rights (Smelter \& Rasch, 1994). A variety of benefits such as progress academically, on standardized tests, and IEP goals, as well as motivation to learn, on task behavior, more completed assignments and positive interactions with 
peers are touted as part of the success of inclusion (National Center for Educational Restructuring and Inclusion, 1995). In addition, students with learning disabilities in an inclusive classroom may feel greater control over their learning, more connected to a classroom and less stigmatized (Shoho et al., 1997). In a study on mathematics, inclusion students were able to perform at the same level as lower achieving students without disabilities in the general classroom (Fuchs, Fuchs \& Fernstrom, 1993). Numerous studies have shown that students in inclusive classrooms reap many social benefits. Capper and Pickett's (1994) study showed that students in an inclusive classroom demonstrated more acceptance, understanding and tolerance than those in non-inclusive classrooms. Another study demonstrated that inclusion facilitated a willingness to develop friendships between students with and without disabilities (Hendrickson, Shokoohi-Yekta, Hamre-Nietupski \& Gable, 1996). Students without disabilities described learning from students with learning disabilities in the general classroom as a positive experience (Murray-Seegert, 1989). Manset and Semmel (1997) found inconclusive evidence regarding the effectiveness of inclusion on students with mild disabilities.

As with any model, there are concerns. Zigmond and Baker (1995) argued that individualized instruction may be reduced for students with disabilities in an inclusive classroom. Another concern is that including students with disabilities in state wide testing scores may bring overall results down. However, studies by Idol (2006) and Sharpe \& York, (1994), did not show significant discrepancies in scores. Another concern has been the impact on students without disabilities in the classroom. Some students reported feeling discomfort when interacting with students with disabilities 
(Peck, Donaldson \& Pezzoli, 1990). Sailor and Roger (2005), argue that inclusive classrooms simply isolate students with disabilities within the classroom and create a distraction for other students. According to studies performed by Peck, Staub, Gallucci \& Schwartz (2004) parents expressed concern that students with disabilities unfairly received more time and attention from the teacher than did the students without disabilities. Hollowood, Salisbury, Rainforth and Palombero (1994) found no differences in planned and observed instructional time between inclusive and noninclusive settings. The concern that academic progress might be impeded has been studied by numerous researchers. Studies show there are no major differences in academic achievement for students without disabilities in inclusive classrooms. (Sharpe \& York, 1994; Hunt, Staub, Alwell \& Goetz, 1994). Peck et al., (2004) asserts that inclusion is likely to benefit students without disabilities.

Advocates of inclusion generally do not prefer pull out or resource rooms (Smelter \& Rasch, 1994). Studies have shown that students with mild disabilities make more gains in inclusive classrooms (Deno, Maruyama, Espin \& Cohen, 1990). However, administrators and educators appear to support inclusion in theory but struggle to do so in practice (Daane, Beirne-Smith \& Latham, 2000). Insecurity has caused administrators and educators to hold onto some special education classrooms. Studies analyzing teacher attitudes regarding mainstreaming were found to be inconsistent (Leyser \& Tappendorf, 2001). Garvar-Pinhas and Pedhazur-Schmelkin (1989) found that teachers had unsupportive feelings regarding mainstreaming. In their study, Leyser \& Tappendorf, 2001) found the opposite to be true. Teachers did not have a negative attitude toward mainstreaming. The study concluded that reasons for lack of support for inclusion may 
be that teachers lack training. In contrast, special education teachers have more training and use more modifications to meet the needs of their students (Blanton, Blanton \& Cross, 1994; Minke, Bear, Deemer \& Griffin, 1996). Both female teachers and teachers with advanced training in mainstreaming use modified instruction more frequently in their classrooms (Leyser \& Tappendorf, 2001). At the conclusion of their study, Leyser and Tappendorf argue the need for more teacher training due to its vital influence on teacher attitudes regarding inclusion.

The resource room which grew in the mid 1980's is slowly being replaced by the inclusion model. The questions of efficacy and cost effectiveness caused special educators to consider alternative programs such as inclusion. Affleck, Madge, Adams and Lowenbraun (1988) found inclusion to be as effective and cost considerably less. Major criticisms of the resource room are the disruptions in the classroom instruction (Wang, Reynolds \& Walberg, 1987), the stigmas associated with leaving the room (Will, 1986), uncoordinated instruction with the general curriculum (Johnston, Allington \& Afflerbach, 1985) and the inability to transfer skills learned (Anderson-Inman, 1986). Haynes and Jenkin (1986) caution not to treat all resource rooms the same. As the push for inclusion continues, the concern of many educators is the need for a collaborative teacher in the general classroom, but for many schools this is not financially possible at this time (Idol, 2006). Although inclusion appears to be an effective model, special education teachers are hesitant to replace the resource room believing pull out is needed for some students (Daane et al., 2000).

Despite major criticisms, the resource room has many valuable aspects. The purpose of the resource room is to provide something extra or different to supplement the 
general curriculum (McLaughlin, 1995). Furthermore, the resource room was designed to specialize learning for individuals. This was determined to be best carried out in a room other than the general classroom. In addition, research has shown that resource rooms have been more successful than general classrooms for students with learning disabilities and emotional or behavior problems (Carlberg \& Kavale, 1980). Smelter and Rasch (1994) advocate that some children still need distinct and special services which cannot be easily brought to the general classroom. They conclude that if the child is better served in the resource room, it is the legal responsibility under LRE to place him there. Espin, Deno, and Albayrak-Kaymak, (1998) reported that IEPs for students with disabilities in a resource room included more individualized instruction, long-range goals and service minutes than students serviced in inclusive settings. According to a study on inclusion by Idol (2006), many teachers still prefer using the resource room and consider it the only way to help some students with disabilities. The resource room is especially important when it supports the general curriculum and teachers collaborate to best meet the needs of their students. Marston (1996) found many special education teachers desire the continued use of the resource room.

Studies on student placement preference are inconclusive. A study on elementary students with learning disabilities revealed student anxiety over both academic and recreational activities that were missed while they were in the resource room (Padeliadu \& Zigmond, 1996). Students in that study also expressed that the resource room was a quiet place where they could focus and receive extra help. Elementary students with learning disabilities also stated that leaving the general classroom was embarrassing even though they liked the assistance from the resource room (Albinger, 1995). Students were 
also worried about the amount of work they would have to make up in their absence. Reid and Button (1995) reported in their study on sixth and seventh grade students with learning disabilities that there was frustration and anger expressed due to being isolated from their peers.

Jenkins and Heinen (1989) studied special, remedial and regular education students to determine their preference for placement and from whom they would like to receive assistance if needed. The students who were normally pulled out to receive help in the resource room preferred to be pulled out. Students who remained in the inclusive classroom desired to receive help in the general classroom. Students who received in class help were split evenly between receiving help from the resource room or in the general classroom. Jenkins and Heinen also found that older students preferred the resource room more than the younger students. Students without disabilities chose the resource room even if it was not the model that was currently used in their classroom. Students that selected the resource room indicated that they thought that the special education teacher could provide better help and that it was not as embarrassing as having the special education teacher come to the classroom. Students that chose to receive help in the general classroom claimed they desired to stay with friends. It was also more convenient and less embarrassing. In studying student preferences for help, Jenkins and Heinen reported that most students chose the classroom teacher because the teacher knew their needs and difficulties, and they liked the teacher. Some thought the special education teacher would not be able to help with generalized education. Other students may have chosen the classroom teacher denying that they needed assistance beyond the general classroom. Students that chose the special education teacher did so because they 
thought the special education teacher would be able to provide more detailed help. In conclusion, Jenkins and Heinen found that embarrassment was a contributing factor in placement preference. Their study also showed that the resource room was not found to be more embarrassing or stigmatizing than in-class services and support.

In his meta-analysis on self-concepts across different placements, Elbaum (2002) concluded there is no overall association between placement and self-concept of students with learning disabilities. However, he does note that a placement may impact an individual student's self-esteem. It is imperative to consider the individual's social, emotional and academic needs when deciding upon the proper placement as well as the student's preference in placement (Elbaum, 2002). Students desire to receive support in the way that is least embarrassing to them (Jenkins \& Heinen, 1989). Therefore, students' emotional needs and desires must be considered before determining the best placement.

\section{Self-concept and Placement}

The majority of a child's day is spent at school, magnifying the importance of the placement decision. The school environment plays a crucial role in the development of academic self-concept and self-esteem that lasts well beyond school years (Markus, 1980). Children as young as preschool begin to make social comparisons although they do not consciously evaluate themselves until around seven or eight years of age (Ruble, 1983). Erikson (1959) noted that the self-concept of an adult is often tied to childhood success and pride or feelings of doubt and inadequacy. Students with mild disabilities struggle to develop critical social skills, have a low self-concept and are not readily accepted by peers (Gresham \& MacMillan, 1997; Haager \& Vaughn, 1997; Ochoa \& 
Olivarez, 1995). Continual academic failure (Leondari, 1993; Grolnick \& Ryan, 1990), separation from the general class (Leondari, 1993; Biklen \& Zollers, 1986, Reynolds \& Wang, 1983), stigmas and labels (Leondari, 1993) can create a self-fulfilling prophecy as well as develop low self-esteem in students with learning disabilities (Good, 1982; Rosenthal \& Jacobson, 1968). According to numerous studies, students with learning disabilities are more likely to develop a poor self-concept than students without learning disabilities (Chapman, 1988; Elbaum \& Vaughn, 2003; Tabassam \& Grainger, 2002). Crocker and Major (1989) disagree, stating that stigmatized and non-stigmatized individuals as a group do not have differing levels of self-esteem. However, in a study of specific components of self-esteem students with disabilities do report lacking in areas of academics, social skills and leadership (Pelham \& Swann, 1989).

According to the labeling theory, students labeled with learning disabilities will be viewed, treated and supported based on their label (Thomson \& McKenzie, 2005). Cooper and Bailey (2001) note that having low self-esteem may be directly related to the response of others due to labeling. In some cases, students with learning disabilities have reported being rejected by their peers, socially unaccepted and expressed feelings of loneliness (Margalit, 1994). In the majority of studies concerning loneliness, students with mild disabilities reported a higher degree of loneliness than their peers (Pavri \& Monda-Amaya, 2000). Leondari (1993) portrays the conflict in placement. A special separate placement promotes segregation which can lead to lower self-esteem. On the other hand, a special separate placement could create less competition, relieve stress and frustrations and may develop positive self-concept. Leondari (1993) concludes that the research is inclusive but notes that the self-esteem of a child with learning disabilities 
largely depends upon how much importance society places on academic success. If a child can find success or perceive himself as successful outside of the academic world his self-esteem may remain positive.

Studies have concluded that students with learning disabilities have a negative self-concept (Cooley \& Ayres, 1988; DeFrancesco \& Taylor, 1985; Kistner \& Gatlin, 1989). Other studies claim that there is no difference in self-concept between students with and without learning disabilities (Coleman, 1983; Kistner, Haskett, White \& Robbins, 1987). Cohen (1985) stated that students in a self-contained classroom did not demonstrate higher levels of depression because they did not compare themselves to higher achieving students. However, studies have shown that students with learning disabilities are able to maintain an overall global sense of self-worth at a level equal to their peers despite lower academic self-worth (Bear \& Minke, 1996; Chapman, 1988; Forman, 1988; Gans et al., 2003). Students with learning disabilities recognized their academic limitations but still felt good about themselves (Bear et al., 2002).

Numerous researchers and studies have delved into determining if placement does have an effect on the self-concept of a child with learning disabilities. Other studies noted no significant difference between self-contained classrooms, complete isolation, and students attending a general education room or resource room. Yauman (1980), Coleman (1983), and Forman (1988) reported no differences in self-concept due to placement in a self-contained or mainstreamed setting. In addition Bear et al. (2002) found that students in self-contained classrooms reported higher self-perceptions in academics than students with learning disabilities that were serviced in resource rooms or inclusive settings. The study also reported that older students with learning disabilities 
had a higher global self-worth in the behavioral domain than younger students with learning disabilities.

Researchers have studied the inclusive classroom and the impact of self-concept on students with learning disabilities. According to Klingner, Vaughn, Schumm, Cohen \& Forgan (1998) the inclusive classroom setting provides opportunities for the development of more friendships between students with and without learning disabilities than the resource room. Students with learning disabilities that began attending an inclusive classroom experienced an increase in friendships and a decrease in loneliness (Vaughn, Elbaum, \& Schumm, 1996). In addition, students in inclusive classrooms were more accepted by peers, and teachers reported fewer behavior problems (Wiener \& Tardif, 2004). The classroom teacher plays a vital role in developing a welcoming and accepting climate in the general classroom (Pavri \& Monda-Amaya, 2000). A study by Fryxell and Kennedy (1995) revealed that students with severe disabilities that were serviced in the general classroom made more social contacts and developed deeper friendships than students serviced in self-contained classrooms. However, students with disabilities in an inclusive classroom were still not picked as most liked and generally picked as least liked in student nominations (Sale \& Carey, 1995). Bear et al. (2002) concluded that students with learning disabilities attending an inclusive classroom did not seem harmed even though they were comparing themselves to their peers in the regular classroom. Inclusion helps reduce stigma (Bauwens \& Hourcade, 1991; Madden \& Slavin, 1983) and develops positive self-perceptions as students participate as members of a classroom (Wang \& Birch, 1984). Another finding asserted that the inclusive classroom would not likely develop positive self-perceptions unless students with 
disabilities were taught not to compare themselves to their peers (Bear, Clever \& Proctor, 1991).

Advocates have often proclaimed mainstreaming and the resource room as the better placement for developing positive self-concept. However, research findings have been inconsistent. Taylor, Asher and Williams (1987) argued that the resource room does not allow students full status as members thus leading to lower social status. Whinnery and King (1995) reported that students with learning disabilities responded that they felt made fun of, dumb and left out more frequently than students with learning disabilities in inclusive classrooms. The majority of students with learning disabilities regardless of placement, felt that the special education teacher helped them achieve better grades. Vaughn and Klingner (1998) noted that the students enjoyed the resource room because it provided the extra help they needed. The students liked it because it was fun but also a quiet place to concentrate. Some students were worried about activities they had missed and some students did not feel they had missed anything. Some students in intermediate grades considered the resource room less embarrassing. In a study on the resource room involving students with learning disabilities and without learning disabilities, Vaughn and Bos (1987) found that students in the elementary grades were less aware of students leaving the classroom than intermediate students. Older students responded more positively toward the resource room perhaps realizing the value of the resource room having spent more time there. The study also revealed that when asked an open-ended question, students did not imply that "resource room" or "special education" meant that a student was not as smart. Albinger (1995) discovered that students do not 
always know why they see a special education teacher. They know they need assistance but do not understand they have a specific learning disability.

The findings regarding self-concept and placement settings are largely inconsistent and make it difficult to determine the best placement. Wiener and Tardif (2004) argue that the issue of placement and self-concept, despite much research, still has not been resolved. They suggest that contextual factors such as lack of appropriate comparisons in differing settings and the difficulty in isolating the emotional component have caused conflict in research. Differences in social and labeling theories may also contribute to the problem. The social comparison theory implies that people look to others in their environment to formulate opinions about themselves in the absence of an objective standard (Festinger, 1954). Renick and Harter (1989) noted in their study that $80 \%$ of students in the resource room compared themselves with their general education peers rather than with peers from the resource room. Still some stigmatized individuals may compare themselves to their own group rather than the dominant group (Crocker \& Major, 1989).

Another noted theory is the "frog-pond effect" in which students with disabilities in a high achieving setting will rank themselves lower in self-perception (Davis, 1966, Pg. 17). These same students would rank themselves higher in self-perception if they were placed in a lower achieving environment. Despite this theory, researchers have reported positive global self-perceptions maintained by areas of competence outside academics (Grolnick \& Ryan, 1990). Conley et al. (2007) reported that students with disabilities do not feel worthless but realize abilities in other areas. Studies have shown that students with disabilities that have fewer academic struggles tend to have a higher 
perception of themselves (Kistner et al., 1987; Kloomok \& Cosden, 1994). Students with learning disabilities have higher self-esteem if they are able to accurately describe personal strengths and areas of weakness (Wilczenski, 1992).

Problems may also lie in the measurement of global self-worth. Rosenberg (1977, 1986) asserts that students may compare themselves within the context of the setting. Therefore, if the setting is the school, students may answer questions of self-worth on the basis of the school context only. Inconsistency in the term learning disability and the construct of self-concept may also be viable reasons for inconclusive data (Silverman \& Zigmond, 1983). Bear et al. (2002) further argues that despite strict criteria in determining learning disability subjects, a particular definition may not apply to other students classified with learning disabilities in a different location. The term learning disability is not well defined and can fluctuate over a variety of settings. The use of differing scales and measurements for self-concept may propose to measure the same thing but may result in varying differences as well.

Many would argue that the connection between self-esteem and placement is not a relevant issue. Wiener and Tardif (2004) concluded their study on the impact of placement on self-concept by stating that one could not conclude that placement plays a major role in the emotional adjustment of a student with learning disabilities. Conley et al. (2007) argued that self-esteem and academic success do not have a significant correlation. Studies have suggested that self-esteem may not always lead to academic success (Damon, 1996; Conley et al., 2007). Howard and Tryon (2002) found that placement did not play a role in self-rated depression scores. Vaughn et al. (2001) argued that some students with learning disabilities do not have difficulties with social skills, 
friendship or self-concept. Some students with learning disabilities are even above average in their scores. Furthermore, they concluded that student perceptions about placement should be considered in the determination of the best placement.

Students are often not considered in the decision making process. They are told rather than asked about placement (Jenkins \& Heinen, 1989; Jones, 1974; Vaughn \& Bos, 1987). Jenkins and Heinen (1989) reported that the feelings of students with learning disabilities about placement are often not considered. Vaughn and Klingner (1998) present the need for student perceptions arguing that all students do not always prefer one placement model over another. Time must be taken to understand a student's perspective in order to guide and determine the best placement. The motivation of student learning plays a pivotal role in academic success and must be considered (Ericson \& Ellett, 1990; Goodlad, 1984).

The majority of research committed to the resource room largely ignores student perceptions and knowledge. Of those students studied, the focus is mainly on students with learning disabilities. Few studies, Shoho et al. (1997), Vaughn \& Klingner (1998), Whinnery \& King (1995), Albinger (1995), and Vaughn \& Bos (1987) have delved into seeking student perceptions and knowledge regarding the resource room. Despite the current trend toward inclusion, the resource room remains a viable service available to mainstreamed children, yet the majority of these studies are significantly outdated. In recent years the resource room has serviced 1.60 million students $\left(24^{\text {th }}\right.$ Annual Report to Congress on the Implementation of the Individuals with Disabilities Education Act, 2002). Current knowledge of perceived benefits and limitations are needed from students with disabilities in order to effectively assess the efficacy of the current placement as well 
as improve in needed areas. Therefore, this study concentrated on the knowledge, perceptions, benefits and limitations of the resource room. 


\section{Chapter 3}

\section{Methodology}

This qualitative action research project focused on analyzing student knowledge and perceptions of perceived benefits and limitations of the resource room as well as suggestions for improvement. The study concentrated on personal interviews with students that attended the resource room. Students were interviewed on the five core questions of the study over the course of several weeks (Appendix A). Interviews were tape recorded and later transcribed.

In addition, teachers and administrators were surveyed regarding the five core questions of the study (Appendix A). The goal of the survey was to provide triangulation in the research. Surveys were returned anonymously, allowing educators to freely express their thoughts and feelings. The five core questions were:

1. What is the resource room?

2. Why do you think you (students) come to the resource room?

3. What are the benefits of the resource room?

4. What are the limitations of the resource room?

5. What are some improvements that could be made? Is there anything you would change? Why? How? 


\section{Rationale for the Method}

Vaughn and Klingner (1998) noted that understanding student perceptions regarding educational views is vital before undergoing educational policy and reform. To effectively understand the views of students, an action research project with qualitative analysis was determined to be the best approach. The results of student perceived benefits and limitations may then drive any educational policy and reform that may be needed. The study focused on the effectiveness and value of the resource room.

The gap in literature regarding the resource room creates a void, especially regarding student perceptions and knowledge. The majority of the literature on the resource room is significantly outdated and is limited regarding private schools. This study focused on determining the value of the resource room. Therefore, this action research project sought to understand students' perceptions as to why they go to a resource room and allow students to freely express their feelings regarding their experiences. The emerging themes from the qualitative data enable students to have a voice in educational issues.

\section{Population of the Study}

The population of this study consisted of elementary and secondary students who attended the resource room at a private school with an enrollment of approximately 170 students. The population was mainly comprised of Caucasian students of average socioeconomic status. The student body was 93\% Caucasian, 5\% Multi-Racial, 1\% Black, 1\% Asian/Pacific Islander. All students were on an IEP or eligible for an IEP. There were five female participants and five male participants. Five students from the elementary and five students from junior high and high school were interviewed. The 
results of this study can be reasonably generalized to private schools with a main service model of the resource room consisting of students with similar characteristics.

Sample

Sample Criteria. The participants of this action research project were students that attended the resource room for less than $20 \%$ of the day. I collected data on 10 out of 13 students that fit this criteria. Three students meeting the criteria did not participate for various reasons. One student no longer attended the school, and one student indicated that she did not have time to perform the study. One student never returned the consent form despite letters and phone calls.

Rationale for sample. The population of this study was limited to students who attended the resource room as this was the intended focus of the study. Therefore, it was impossible to achieve a random assignment of students due to these criteria. Saturation was met by interviewing and collecting data on 10 out of 13 possible students allowing for adequate external validity.

Methods of sampling. Students attending the resource room were determined by need based on IEP or eligibility for an IEP. Sampling from the population was based upon this. The sample consisted of students from a small private school whose main service model was the resource room.

Procedure

Instruments. The main instrument for data collection was student interviews. Students were interviewed on the five core questions of the study. The data was recorded and later transcribed for further analysis. Data was also collected from educators and administrators by a survey with the five core questions of the study. Surveys were 
returned anonymously. The five core questions were based on the five constructs of the study: knowledge, perceptions, perceived benefits and limitations and suggestions for improvement.

1. What is the resource room?

2. Why do you think you (students) come to the resource room?

3. What are the benefits of the resource room?

4. What are the limitations of the resource room?

5. What are some improvements that could be made? Is there anything you would change? Why? How?

Data collection methods. The main type of data collection was comprised of student interviews. Students meeting the criteria were interviewed during a free time in their day. Elementary students were interviewed during lunch or recess time. Junior high and high school students were interviewed during a study hall. This was designed so that students would not be pulled out during class time. Every student was asked the five core questions. Notes were taking during the interview, and the interviews were tape recorded and later transcribed. Certain students that had attended resource rooms at another school were often asked additional questions to gain a wider perspective on resource rooms.

The second set of data collection came from educators and the administration. Educators and administrators were given a brief overview of the study before receiving their surveys. They were asked to return their surveys to the school secretary to preserve anonymity. Data was not collected until all surveys had been returned.

Relevant ethical considerations. There was no harm posed to students or teachers in this action research project. Care was given to ensure that students were interviewed 
only during their free time so as not to interfere with learning. Active informed consent was obtained from both parents and students (Appendix B). Parents gave permission for their child to be interviewed and tape recorded. Parents and students were informed that confidentiality would be maintained. All names used in the final report are changed to preserve identity. Although both parents and students had signed the permission slip, prior to the interview students were again asked if they were willing to participate.

Active informed consent was also obtained from educators and the administration (Appendix C). Educators and administrators gave permission for their responses to be used in the final report. Surveys were returned to the school secretary who kept the surveys in an envelope in order to maintain anonymity.

Methods of data analysis. All interviews were transcribed and organized by question. A chart was created for each question with a division between elementary and junior high and high school responses. Emerging themes appeared during the coding of the data in comparing student responses. The chart organized the themes that appeared in both elementary, junior high and high school responses and those that were apparent in only one category. A master list of codes emerged from analysis of the data based on the charts.

A similar process was used in the data analysis of the teacher surveys. The surveys were organized according to question and each response was re-typed in order to see all the responses for the same question at the same time. Elementary, junior high and high school teachers and administrators' surveys were organized separately. A chart was created for each question and divided between elementary, junior high and high school teachers and administration. Emerging themes appeared during the coding of the data in 
comparing educator responses. The chart organized the themes that appeared in all responses and those that were apparent in more than one or only one category. A master list of codes emerged from analysis of the data based on the charts.

Safeguards to internal and external validity. In order to combat researcher bias in an action research project, I used self-reflection as a means to balance. During the study I specifically looked for negative-case sampling, responses that would not support my expectations. In the section on limitations I purposely asked each student if leaving the general classroom bothered him. I have also explained the potential influence of my background on this study in the discussion section.

The students that attend the resource room were all IEP students or were eligible for an IEP. However, the students are not classified as having the same disability. This could cause a difference in understanding the questions as well as viewpoints and perceptions. A separation of students according to disabilities would have created problems with small sample sizes and could lead to the results being misinterpreted. Therefore, the students in this study were placed in a single category. The goal of this study was not to point out characteristics within each disability, but to study the knowledge and perceptions of the students attending the resource room.

In the analysis of data, low-inference descriptors were used. Care was taken to include direct quotes whenever possible and to use words that similarly expressed the student's viewpoint if exact words were not possible.

Internal validity was constructed by using both methods and data triangulation. Both interviews and surveys were used to create methods triangulation. This ensured that more than one method was used in collecting data. Data triangulation involved 
researching both student and educators' knowledge and perceptions. Data triangulation helped to gain an internal student viewpoint as well as an external educator's viewpoint. External validity is weaker due to the fact that no random sampling occurred within the data population. Therefore, the results are not widely applicable. However, the goal of the research was an action project focused on the resource room. Haynes and Jenkins (1986) cautioned that resource rooms cannot be treated the same. Differences in teachers, students and differing types of disabilities can change the variables within each resource room. The results of this study can be generalized to resource rooms with similar students and similar characteristics even though a larger target population may not be possible. 


\section{Chapter 4}

\section{Qualitative Analysis}

This study analyzed student knowledge, perceptions and perceived benefits and limitations of the resource room as well as suggestions for improvement. Students that attended the resource room and were on an IEP or eligible for an IEP were interviewed. Interviews centered on five core questions concerning the explanation of what the resource room was, why students go there, benefits, limitations and suggestions for improvements. Interviews were tape recorded and later transcribed for further analysis.

As a secondary study, educators and administrators were surveyed regarding their knowledge and perceptions of the resource room. Educators and administrators were asked the same five core questions in order to better understand the educators' perspectives on the resource room and compare it to that of the students.

Educational policy and reform is often made without the input of the students, although changes directly affect them. Analyzing student knowledge and perceptions regarding the resource room gives students a voice and allows educators to best meet their needs. Students described the benefits of the resource room as a valuable place to receive assistance. Students noted the value of a specialized teacher, quiet atmosphere, 
and a better understanding of school work. Students also expressed limitations of the resource room as being interrupted during work and preferring to stay in the classroom to complete assignments. Students provided suggestions for improving the resource room as well. Suggestions included changes in the physical room as well as increased independence.

\section{Description of the data}

Students that attended the resource room were interviewed in order to gain an understanding of the breadth and depth of their knowledge and perceptions of the resource room. Students were interviewed during a free period so as not to interfere with learning. Most interviews were 5-10 minutes and all were centered on the five core questions of the study. Interviews were tape recorded and later transcribed. After transcription of the data, the data was analyzed and coded as emerging themes appeared in segments of the data. These themes were organized into a chart to simplify comparison between elementary and junior high and high school data.

\section{What is the resource room?}

Art room. Elementary students overwhelmingly indicated that the resource room is known as the art room. Four out of five students indicated that the resource room was the art room. In this particular study, the resource room is shared with the art room and was formerly a computer lab. Eric illustrates this when he said, "It's the art room. It has cabinets like that and it was the computer room, but they changed it to the art room." Jill stated, "It's in the art room." She later clarified by saying, "I go to her room to do reading and math." Only one student interviewed from the elementary classified the room as a 
place to receive assistance. Kelly responded by saying, "Well I think it's to, like, help kids have a quiet room to just take their tests, and if you, like, understand the words and stuff she reads it to you."

Only one elementary teacher classified the resource room as the art room. The teacher wrote that the resource room "is a room used for art and for a tutor session" indicating that art was not the sole purpose of the room.

A place to get help. In junior high and high school only one student classified the resource room as "the art room and nice" but later added "she helps a lot...math, reading." In contrast, junior high and high school students indicated that the resource room was a place where one could receive help. Chris said, "Mrs. Mitchell's room is where she helps students that are having difficulty in their work and helps them improve their work so they can get a whole lot better at it." James answered in a slightly different way. He stated, "Where if you need help with a test or homework you can get it." Krista similarly answered, "It's a room in order to get help for people that need help in school work." Josh saw the resource room in a different light. He noted, "It's like somebody... to help... that can't learn as fast."

Elementary, junior high and high school teachers as well as administrators overwhelmingly agreed that the resource room was a place where students could get extra help. Elementary teachers wrote it was a room where student could get "extra help" and "the resource room was designed to give additional help to students who need it". One elementary teacher described the room as "an area used for remedial work to be accomplished at the student's level". Some described it as a "place where students go to 
receive individualized tutoring or instruction with a trained teacher/specialist" and a "room that is used for... a tutor session".

Junior high and high school teachers described the room as "a place where a student can receive a higher concentration of subjects" and "to provide them additional support to be successful in the classroom environment". Others wrote "a place where students can get extra or special help" and "the resource room is an area where students can get the extra help they need academically". One reported it was "an opportunity for students to improve their academics". Two teachers described the room in terms of how a student might see it. They described it as "a haven for students needing extra help" and "a private space where students can work one on one". Two teachers described the room as a resource not only for students but for teachers. It "has things teachers and students can use to help us". Another wrote, "It is a resource I can use as a teacher to gain insight into helping my students with special needs."

The administration described it similarly but included more specific terms. The resource room was described as "a place where students can get extra help with completing assignments, review concepts for tests, get assistance with taking and/or reading tests, and overall improve their learning". Another wrote, "the resource room is an area where students who need extra individualized assistance go to complete tests, assignments or other work". One replied that the resource room teacher "teaches the students to learn a little more, try a little harder and think a little clearer...encourages each student to use [his/her] own methods of learning".

Accommodate IEP students. No students stated that the resource room was for students with learning difficulties, IEP students or students with special needs, although 
these terms were all included in the responses from teachers and administration. Only one student implied this with his statement "it is for somebody... to help...that can't learn as fast." Elementary teachers described it as "a place for accommodations for IEP" and a "room where our students go down to if they have IEPs". Another wrote "only students with IEPs are able to access the resource room".

Junior high and high school teachers used the phrases "students that have learning difficulties," "students that have special needs," "a place to help students that have identified special learning needs" and "mostly for IEP students but also students identified as needing help in a weak area... not necessarily IEP students”. Another wrote "This need for help is decided by testing the child or by teacher observation, evaluation and recommendation".

Only one administrator described it in terms of accommodating a student on an IEP. "It is a room in which students who are identified as special needs or who are on an IEP or service plan go for academic assistance and intervention." Why do you think you come to the resource room?

Take tests and quizzes. Elementary students differed in their perceptions of why they came to the resource room, but many agreed they came to take tests and quizzes. Eric said, "For tests and quizzes". He was later asked why he thought he went there to take tests and quizzes. He responded by saying, "Mrs. Tillman tells us to." Annie indicated that she also took tests and quizzes in the resource room but stated it was mostly, "... for checking tests and quizzes". When asked if she went to the resource room to take tests and quizzes Jill answered, "Tests. Just tests." She explained that she spelled 
the words and the resource teacher would write the answers down for her. Kelly also said she was helped with "just tests and quizzes and stuff".

Junior high and high school students also expressed that they went to the resource room to take tests and quizzes. Tina said she goes as needed and to "study for a test...I take them sometimes in the room and sometimes with her". Tina explained that the resource teacher reviewed concepts with her. "Like she will go over the stuff I need to know and then she will like ask me questions and then I'll tell her." Josh noted that he takes tests in the resource room. "For me it's English and sometimes in Bible."

Both teachers and administration also indicated that students go to the resource room to get help with tests, quizzes and homework. One elementary teacher wrote that students take "tests/quizzes down there". Another replied that students "take tests, quizzes in a quiet, less intimidating/distracting environment”. Junior high and high school teachers indicated that students go "to have tests read to them out loud" or "for extra academic assistance - explanations, reading tests to students”.

Only one administrator wrote that "tests are administered" in the resource room. The other three administrators did not indicate this was a reason students go to the resource room.

To do work and learn. When asked why he went to the resource room, Caleb's response was "to do work". After further prompting he explained he did math, science comprehension checks and language in the resource room. The resource teacher "reads the questions" on the science comprehension checks to help him. Caleb admitted that "She lets me play the DS" for math games "because it's fun". Eric also uses the DS for math games. Eric indicated he did math and reading in the resource room as well. Jill 
said she went "to learn...to read...to learn some more stories...math...We do adding, subtracting and times...We do spelling words too."

An elementary teacher said students go "to get extra support guidance for their studies... and [work] on writing". Another wrote they "receive additional practice or remediation with specific skills/activities, receive individualized instruction...learn skills and strategies for accomplishing specific tasks." One junior high and high school teacher said students receive "assistance on homework".

Quiet atmosphere. One student clearly expressed that she went to be in a quiet environment in order to do her best work. Kelly said, "For a quiet place... some people like to talk." She added, "and she kind of helps us understand".

One elementary teacher indicated that students "take tests, quizzes in a quiet, less intimidating/distracting environment". Junior high and high school teachers and administration did not indicate on their surveys that students go to the resource room because of the quiet atmosphere.

To get help. When asked why she went to the resource room Annie said, "To get help when I need help on work... whenever I need to basically.” Although she was the only elementary student to state clearly getting help as a reason for going to the resource room, the majority of junior high and high school students stated this as their main reason. Tina responded, "To get help and to try and get good grades." She expressed that she had help with math and reading. "I see her every Monday for math."

Some junior high and high school students were able to acknowledge a personal need to visit the resource room. Krista specifically stated that she needed help due to a learning difficulty. "I'm [on] an IEP and I have a hard time reading, so I get help 
whenever I need it from her...anytime I need help I just go in.” Josh also specifically knew why he went to the resource room. He goes "To get a lot of help...math, English. For me it's mostly English". He further clarified how the resource teacher helps him. "She like re-says it out loud to get a better concept of learning." Josh said he was able to go to the resource room "when I need help". Chris stated, "I know that I need help on the stuff that I don't know much about...like math and English." He also indicated he is able to go to the resource room whenever he needs to go.

One high school student did not acknowledge a personal need and expressed that he did not want to go to the resource room. James said he went "because my mom and the teachers thought I needed help. I didn't really want to. It seemed like a waste of time". James no longer attends the resource room although he does have an IEP. He felt that the resource room did not help him. James said, "She just basically read the questions to me and stuff like that, and I could already do that."

Teachers and administration indicated that the resource room helps students improve or succeed. Elementary teachers described this help as "remediation," "extra support guidance," "extra help with their studies," and "receive additional practice or remediation with specific skills/activities...receive individualized instruction...learn skills and strategies for accomplishing specific tasks". Sometimes elementary teachers referred to this help as a tutoring session. "Students go to the resource room for individualized or group tutoring." Another wrote, they "receive individualized instruction".

Junior high and high school teachers described the help as "individualized assistance with their school work/tests," "students may need help...on a more individual 
basis" and "so they can improve". Teachers used terms such as "extra academic assistance," "additional help," and "help in an area of weakness so they don't get behind". One teacher wrote that students get help from a variety of sources. Students receive help from the resource teacher, "school psychologists and other workers".

The administration reported students go "to get academic assistance so that they can better understand the material they've been encountering in their regular classroom". One said, "the resource room is ordered in such a way that daily schedules are consistent... and students are genuinely given the opportunity to be successful in verbal or written fashion."

Accommodate IEP students. The majority of junior high and high school students knew that they needed help with their work. Only one student reported that she went because she was on an IEP. However, teachers and administrators recognized that part of the reason students attend the resource room is to accommodate their IEP requirements. An elementary teacher wrote that students receive help if "a gap exists between their abilities and that of their classmates". Others said it was "accommodations for IEP students" and students "on IEPs go there to work".

Junior high and high school teachers indicated the resource room was for "students with and without IEPs" and that there is a "discrepancy between performance and ability or students have been on an IEP at their former school". One teacher described the students as "needy when it comes to academics".

One administrator wrote, "Students are entitled to tutorial assistance mandated by the state if they are identified as IEP or 504 service plan." Another said that "students who are on IEPs or in need of additional assistance" are able to use the resource room. 
Challenge students. Only teachers and administrators reported that students go to the resource room to be challenged. Elementary teachers said that "occasionally a student might be able to go for challenge work" and mentioned the eagles gifted program for "students that excel". Only one junior high and high school teacher wrote that students "may need to be challenged on a more individual basis" as a reason to attend the resource room. One administrator also noted that "students with IEPs attend the resource room as well as gifted students".

\section{Benefits of the resource room}

No specific benefit. For some elementary students, it was difficult to express what the benefits of the resource room were. The question was reworded to facilitate better understanding. Students were asked what they liked about the resource room as opposed to listing benefits. Annie initially responded that she liked, "Anything really. I like going there. I just like it. I don't know why." Eric also struggled at first. He replied, "I don't know." However, later he was able to identify several reasons with prompting. When asked, Jill immediately responded, 'It's awesome. It's fun working in there." When questioned further she revealed she liked to "learn about animals and stuff...to do math in there. I like to do adding and subtracting and times". On the other hand, junior high and high school students were able to express a specific benefit of the resource room.

Help with school work. Two elementary students positively responded that they valued the help they received on school work. Eric stated that he liked to do homework there because "she writes all of it". When he was questioned as to what the resource teacher did to help him he answered, "She tells me... to do it by myself". Although Jill 
struggled at first as to why she liked the resource room when questioned further she revealed she liked to "learn about animals and stuff...to do math in there. I like to do adding and subtracting and times". Kelly added, "Sometimes I don't really understand things and she, like, reads them and, like, helps. If you, like, don't know she'll kind of do all she can to explain it and stuff." Kelly was questioned as to whether she noticed a difference since she began attending the resource room to take tests and quizzes. She said, "Yes. It's been very helpful."

The majority of junior high and high school students also responded that a main benefit of the resource room was the assistance they received. Chris stated, "It's pretty good since I have someone that can help me with my work. She helps me understand it more than when I read it." Chris indicated that the resource teacher helped him by reviewing and re-teaching things for him. Krista listed two benefits of the resource room. She said, "Good grades, [and] better understanding in school work." Josh expressed the benefits this way. "The good thing is I can get better learning experience. I get to know what I'm supposed to do."

The majority of responses from teachers and administrators indicated that the help received in the resource room was a clear benefit. Teachers and administrators specifically described the help as both extra help and one on one help. Elementary teachers said a benefit of the resource room was that "students get extra help...to comprehend a topic". "It helps the student who has difficulty to improve." Another wrote there is "individualized or small group attention level".

Junior high and high school teachers spent a good portion on their surveys describing the benefits of the extra help. In particular the teachers noted the level of one 
on one teaching that the student received. One teacher wrote, "It allows students a greater one on one attention in subjects that they might not be able to receive in the classroom." Another said, "These students have individualized help, instruction, one on one and apply special needs." One teacher added, "It gives the child the opportunity to have some one on one contact with a teacher to reinforce objectives that have been introduced and practiced in the classroom. It allows a student to get back on track academically." Another teacher wrote, "It provides one on one help to individual or small groups of students." "Another benefit is one on one instruction from the resource room teacher" noted a junior high and high school teacher. Teachers described the help as "a resource for furthering the understanding of school work. This allows the teacher to administer to the necessary needs of each student with limited time and room." The resource room can help students "utilize tools to help them learn more." One teacher noted the benefit of "assistance strategies to help my students" and said it "defines the needs of my students". One administrator wrote that going to the resource room "allows students to get extra help understanding concepts they are struggling with".

Environment. Elementary students perceived the learning environment to be comfortable and quiet. At first Annie struggled to describe what she liked about the room. She finally described the resource room as "It's small. That's what I like. It's comfortable to me". Eric said he liked the physical features of the room when asked what he liked about the room. "It has many colors. It has a cabinet." Two students particularly liked the quietness of the room. Caleb stated, "It's quiet." and indicated he was able to concentrate better. Kelly added a bit more to why she liked the resource room, "Just the quietness and you can just like take your test in peace and stuff." 
The environment was also a noted benefit of teachers and administrators. Elementary teachers described the environment saying, "The room is quiet. There is enough room for students to work." Another wrote the room "removes [the] student from possibly stressful situation[s]" in the general classroom. It has "fewer distractions" was added by another teacher.

Junior high and high school teachers used terms such as "private space...that allows the students a quiet place, time..." and "it also provides a quiet environment for extra practice or test taking". Another teacher described it as "a place where no issue or problem is too big".

The administration described the environment as "a relaxed non-threatening environment" and as "quiet and therefore [the] focused learning that takes place is invaluable to a student with a weakness for distractions". One administrator commented it is a "separate place that is quiet for the purpose of individualized instruction. It is a place where they are able to focus and concentrate and work at their pace. The resource teacher has the ability to create a class-like environment without the same number of students (i.e. tables to sit at, chalkboard and other resources to use, even one or two other students who are there at the same time). Another benefit is that it is a stable place for students to complete their individualized instruction. Students know where the resource room is. Whereas some instruction may be conducted in a meeting room, library, or hallway, the resource room is consistently used for this individualized instruction (with the exception of art periods)."

Resource room teacher. Many junior high and high school students referenced the fact that having a teacher to help them was a major benefit of the resource room. As 
mentioned earlier, Chris stated, "It's pretty good since I have someone to help me with my work." Krista explained that the kind of teacher matters when she said, "A willing person to teach that doesn't yell at you." Tina commented on the resource room teacher as the reason she liked the resource room. "She is nice, and she's sometimes funny."

Teachers and administration recognized the value of the resource room teacher. One elementary teacher wrote there is a "teacher specially trained for intervention teaching". A junior high and high school teacher put it this way, "The classroom teacher is not always able to meet the need of every student" indicating that the help of a resource teacher is a benefit of the resource room. One teacher said the resource room teacher "is the benefit. She is gentle and bold with motivation. The kids love her and learn from her. She takes teachers' input". The administration added "students get a one on one assistance with a certified learning disabilities teacher". Another administrator said, "the time that Mrs. Mitchell spends one on one is priceless for the student who just needs more time to understand a particular concept."

Friends. One elementary student expressed that the reason he liked to go to the resource room was "Because...Caleb and me go there". Eric indicated that he liked to take tests and quizzes because Caleb got to go with him.

No benefits. One junior high and high school student found no benefits of the resource room. James no longer attends the resource room as he felt it was a waste of time.

\section{Limitations of the resource room}

Nothing. Two elementary students responded that there were no perceivable limitations of the resource room. Caleb indicated that there was nothing he did not like. 
When questioned if he was sure, he responded, "I'm sure." Annie was asked if there was anything she did not like about it. She stated, "Nothing really."

Three junior high and high school students also responded similarly. Chris said he did not perceive any limitations. Krista answered, “I don’t think anything." Tina positively said, "I like everything about it."

Taking tests and quizzes. Two elementary students preferred to stay in the general classroom to take their tests and quizzes. Eric said, "I want to stay there for...tests and quizzes." Previously in the interview Eric had said he liked going with Caleb to take tests and quizzes. When he was questioned as to why he wanted to stay in the classroom, he was unable to give a clear response. He said, "I don't know." Jill said she did not like taking math tests in the resource room because "it's hard". She would prefer to take her math tests in the general classroom.

Environment. One elementary student noted that "Sometimes there's high schoolers in there and it's kind of crowded sometimes. And it's right by the high schoolers so whenever they like get done a subject they're always like noisy going down the hall". Kelly admitted that it ruined the quietness that she liked about the resource room.

One high school student, Josh, admitted, "I can't focus straight...sometimes in her room." However, he also explained that he had trouble focusing in the general classroom. He could not explain exactly what made it difficult to focus.

Despite few complaints by students, teachers and administrators overwhelmingly agreed that the environment of the resource room could be more conducive to learning. One elementary teacher indicated that it was also the art room and wrote "The students 
don't have an individual space to work - only the cafeteria tables to work at" and indicated that the room was "not always available". Another teacher echoed that sentiment with the response that the resource teacher "needs a space where she is not preempted for other events." One teacher said it's "not a real room".

One junior high and high school teacher said the resource room "is a bit small. There are other things (storage) that go on in there (interruptions)." Another noted the sharing "between high school and elementary" and "Mrs. Dillard for art purposes" as a problem. One administrator noted, "The major limitation of the resource room is that it is a shared room used also for art instruction." Another added, "The limitations of the resource room are reflected in the physical arrangements of the room. Mrs. Mitchell shares this space with the art teacher. Although no classes are scheduled in this room during tutoring times, the students' learning it seems reasonable to assume, would be influenced by the long tables and uncomfortable round seats. Along these same lines the whiteboard is not conveniently located for Mrs. Mitchell to demonstrate concepts. (The board does not clean up well.) Finally, if Mrs. Mitchell had her own room this would better facilitate the needs of the student and teacher."

Leaving the general classroom. All students were specifically asked if it bothered them to leave and go to the resource room. This was not a core question but was used as a validity measurement in order to determine negative-case sampling. Three out of five elementary students responded that it did not bother them to leave the general classroom. One student, Eric, stated, "I want to stay for...tests and quizzes." However he seemed to be unsure of what he thought. When asked if he was confused about what he thought, he indicated that he was. Annie explained that it did not bother her to leave the classroom 
"except when I get off track in what we're learning". Annie indicated that it was hard to catch up on her work. None of the elementary students expressed that leaving the classroom had a stigma associated with it.

Three out of five junior high and high school students responded that it did not bother them to leave the general classroom. When asked if it bothered him to leave, Chris said, "No, it doesn't." James replied, "It was fine." Tina immediately said, "No." Josh admitted that it did bother him to leave "a little bit". He did not explain why. Later in the interview he was asked if there was something that could be done to make leaving the general classroom easier. He responded, "Probably not." Krista had never thought about whether or not leaving the classroom bothered her. She answered, "I don't know...You caught me off guard. I don't know." She later admitted that being talked to by the resource teacher in study hall was embarrassing for her. "It kind of embarrassed me when she came up and talked to me. Like sometimes she will come up and be like, so you need to come in, you know, so I can help you and stuff and that would make me kind of embarrassed." Krista explained that what made it embarrassing was that it occurred in front of her friends in study hall. Krista later clarified, "She's just caring and was trying to get me help."

This did not seem to be a limitation noted by teachers and administration. Only one administrator mentioned, "Sometimes (not necessarily here) students may be labeled by their peers as being 'LD' or 'slow'".

Unwanted help. One high school student expressed a few specific limitations of the resource room. He did not want to receive help in the first place. James said, "Things were a waste of time. It was stuff I already knew how to do and everything. Everything 
would take longer, so I wouldn't have time to do all my homework." For James, going to the resource room made things harder for him as it took longer. He also felt that he was capable of doing things on his own and did not need to go to the resource room.

Time restraints. Although not a limitation mentioned by students, teachers and administrators felt that there were many time restraints that created limitations in the resource room. One elementary teacher said, "time restraints limits full class discussion and interaction." Junior high and high school teachers saw time constraints as more of a problem. One teacher wrote in response to limitations "I can only think of the amount of time available based on the number of students attending." Another said "Limitations seem to be the sharing between high school and elementary as well as sharing the room with Mrs. Dillard for art purposes." "There is never enough time to service all the other students who could use a little extra help or even just some one on one time. IEP students require first spaces" responded a junior high and high school teacher. One teacher stated briefly “too many students, time limitations, sickness, [and] days off” as another reason.

Part time teacher. Especially apparent among teachers and administrators was the concern of having only a part-time resource room teacher. An elementary teacher noted that the resource room teacher "is only one person" indicating that there was only so much one person was able to do.

One junior high and high school teacher said, "Mrs. Mitchell is wonderful but she only works part-time. She is really needed on a more full time basis." Another teacher explained by stating "A lot of students are pulled out of larger public schools because they aren't having success there, so I believe [we have] a large percentage of its student 
body that need extra help. I would say that we need a full time tutor/teacher in the resource room to be of assistance to the regular classroom teachers and so every student that has special needs can have equal access." The responses "Mrs. Mitchell is only present in the morning and often has many students working on many different activities" and "We don't have [Mrs]. Mitchell full time" echoed the limitations other teachers noted. One administrator coupled the limitation of time restraints with the need for a part-time teacher by writing "One major limitation of the resource room is the amount of time Mrs. Mitchell is available to work with students and the fact that Mrs. Mitchell is responsible for assisting all struggling students in kindergarten through $12^{\text {th }}$ grade.”

Scheduling conflicts. Only elementary teachers and one administrator perceived a limitation in scheduling time to meet with the resource teacher. One teacher listed three scheduling conflicts in her response. She said the problems were, "Scheduling of Mrs. Mitchell's time, scheduling and releasing students from class, grade level, [and] scheduling of special events at the school that interrupt academics." Another wrote a slightly different concern with scheduling, saying, "[A] student misses class time and cannot always be pulled from the subject area intervention is needed in." One administrator indicated, "The major limitation of the resource room is that it is a shared room used also for art instruction. Scheduling times for students around the art schedule is a workable challenge."

More materials. Elementary teachers also found a limitation in the number of resources and materials available in the resource room. One teacher felt "it needs more manipulatives for Mrs. Mitchell's to use: chalkboard/dry erase board, an area for Mrs. Mitchell's supplies, phonic, math or other helpful posters on the wall. She would be able 
to refer to them when needed." Another wrote, "Mrs. Mitchell needs her own space where she can accumulate teaching aids."

\section{Suggestions for improvement}

No changes. One elementary student, Eric said that he didn't have anything to change about the resource room, although he did change his answer a few times. Although Annie did want to change the color of the wall, when she was asked about changes concerning the help she received she indicated that she would keep everything the same.

Two high school students similarly responded that they would not change the resource room. Josh said, "I don't have anything to change." When asked if she would change anything, Krista replied, 'I don't think so. My grades are all right now, but if I need help I always go to her."

Physical environment. Three out of five elementary students stated that they would like to change some physical aspect of the resource room. Annie said she would change "the color of the wall" to blue because it was her favorite color. Caleb indicated that he wanted more people to be able to go to the resource room with him. Caleb said he would change "how big it was." When questioned why he responded, "So we could have more people in it." Kelly expressed that she wished the resource room could go back to its former location. "Since it's moved, I wish it could go back to its original spot. It just like, it feels cozy in there for some reason." Kelly explained that the current resource room does not have the same cozy effect. "It's kind of like the art room where everything is hanging up and it kind of distracts." She closed by saying, "I like it." 
Only one high school student expressed an interest in changing the physical environment of the room. Tina also responded she would like to paint the room. She wanted the colors to be blue and pink as they were her favorite colors.

Educators and administrators were able to list a few improvements in regard to the physical environment of the resource room. One elementary teacher suggested "a room that is more centrally located in the building since Mrs. Mitchell services high school and elementary students." Another said, "Dedicate a room just for the resource room." One teacher wanted the room to be more comfortable: "I would like to see the room be more inviting for students, a more comfortable way to learn.”

As a suggestion for improvement, one junior high and high school teacher wrote: "A more comfortable learning environment - chairs, desks, computers, smart board, not the lunch tables." One teacher said the "students and Mrs. Mitchell could use their own space. I am also sure Mrs. Mitchell could use more resources.” Another simply said an "extra room" was needed. Two teachers noted that a change was necessary but might not be feasible. "I don't know that there is an effective change for us currently with our building size, but the addition of another room for art...would be a positive direction to take." Another said, "If we ever had a bigger school I would build a larger room with more privacy." One teacher wrote the school should "ask Mrs. Mitchell what she needs and do everything in our power to get it."

One administrator commented, "Improvements that could be made would include: a separate room only for the resource instructor, storage space for remedial instructional materials, [and] enough laptops/desktop computers for students to use in the room." Another wrote, "More access to technology would provide more practice to each 
student's learning, as well as free up Mrs. Mitchell during repetitious activities for student practice. Technology could also provide a variety of curriculum opportunities."

Subjects. One elementary student expressed a desire to change the subjects in which she received help. Jill stated, "I would change different subjects...math, history and science." When questioned why, she replied, "Because they are going to be easy," indicating that subjects completed with the help of the resource teacher were easier for her.

Help Received. Two high school students indicated that they would like to change some features as to how they received help. James felt that he did not need the help of the resource room. When questioned as to what could have been changed to better meet his needs, he responded, "I don't know, maybe, being able to figure out more of what the student wants to have help with." James expressed that he wished someone had asked him whether or not he needed help and in what subject areas. Chris wanted to change to only going to see the resource teacher after he had first tried to do the work on his own. He said, "I should go there if I really need help. But I should at least try it myself first. And if I don't get it, then I'll just go to her." Chris indicated he had been receiving help in the resource room for three years and felt he was ready to be more independent.

Full time teacher. The majority of teachers and administrators noted the limitation of a part-time teacher and suggested that the resource room teacher be full time or to hire an additional teacher to help. One elementary teacher wrote, "Give Mrs. Mitchell some help. Hire another teacher to help more students and be more available." Another said, "I would like to have more time with Mrs. Mitchell. It is definitely worth 
it!" One teacher put it another way, "Additional funding is needed! A part-time person is not enough to service the needs of the school. Also, if we had more accessibility, students who do not have IEPs, but need extra help would be able to be serviced."

Junior high and high school teachers responded similarly. One noted an improvement would be "possibly another resource teacher" although mentioned that this might not be feasible with the current building size. One teacher coupled the need for serving more students with the need for a full time or additional resource room teacher. "I would like to see Mrs. Mitchell able to serve more students on a daily basis. She works so diligently but there are only so many hours that she works and only one of her to go around." Another suggested the need for a "full time teacher in the resource room" and stated, "I'm not sure how many hours Mrs. Mitchell works." Another echoed with a simple statement of "full time teacher, more teachers" in summarizing needed improvements.

All four administrators also felt that a full time or additional teacher would be an improvement. "It would be nice for Mrs. Mitchell to be able to devote more time to individual students and/or grade levels but at this time [it] can't be done due to the financial aspect." Another said, "It would be beneficial if Mrs. Mitchell were more available more hours, for students." One administrator suggested, "The resource instructor to be here on the campus full time." This was echoed by another administrator "More scheduled time for Mrs. Mitchell to be in our building would definitely be a help."

Scheduling. Also noted as a limitation, scheduling was listed as an area for improvement as well. An elementary teacher responded, "It would be helpful if scheduling were more flexible and afternoon times were also available." One 
administrator wanted to schedule additional testing for the resource room teacher. "If Mrs. Mitchell could attend or provide placement testing before we accept a new student... this would help balance student needs within our school."

More communication. An elementary teacher commented "It is difficult to talk to her for short student updates. Communication is difficult due to many different schedules. [It would be helpful] if there were regular times to meet with her per grade level, [and] quarterly reports written to parents that give suggestions and observations about the student she is working with." One junior high and high school teacher also commented it would be helpful to have "[a] conference with Mrs. Mitchell to review my special needs students at the beginning of the year".

Additional Comments. Educators and administrators had the option to leave additional comments if they felt necessary. One resource teacher wrote: "Unless we are able to obtain additional funding for a resource teacher, I do not feel it is okay to accept any more (number wise) students with special needs," indicating it was not "fair to the individual student or the classroom". Three other teachers commented on the resource room teacher. One elementary teacher said "We love Mrs. Mitchell." Another wrote "Our current resource room teacher does an excellent job with the time and resources available to her." A junior high and high school teacher stated, "Mrs. Mitchell does an excellent job. We are blessed to have her. God will provide when we need it."

\section{Summary}

This study allowed students to voice their knowledge and perceptions of the resource room. In addition, a secondary study of teachers and administrators provided a backdrop from which to understand these voices. Students perceived three major benefits 
of the resource room: ability to receive help, the resource room teacher and the environment. Perceived limitations were few and varied from student to student. Students did not offer many suggestions for improvement with the exception of help with subjects or changing the physical environment. 


\section{Chapter 5}

\section{Discussion and Implications}

This study focused directly on student knowledge and perceptions of the resource room. The findings indicated there are numerous perceived benefits of the resource room. Students noted benefits as the ability to receive help, a quiet environment and the resource room teacher. Limitations perceived by students were minor. Students wanted to change the physical environment and the amount or type of help received. Students' voices regarding their perceptions of the resource room enable educators to best meet their needs. Practical applications and comparisons to similar studies are also presented. Interpretations of the Results

What is the resource room? The majority of elementary students in this study referred to the resource room as the art room. Some students did clarify their answers when further questioned, but their initial response indicated where the room was housed rather than what the purpose of the room was. In contrast, junior high and high school students overwhelmingly responded that the resource room was a place where students could go to receive help. The differences in responses may be due in part to the age of a student. Elementary students did not appear to understand the purpose or nature of the resource room. They simply knew they went to the resource room, and it was also the art 
room. It appears that an understanding of the resource room does not come until a student is older. The student that has had more years attending the resource room appears to come to a better understanding of its function. The resource room has always been referred to as "Mrs. Mitchell's room". It has not been called the resource room prior to this study.

All educators and administrators agreed that the resource room was a place where students can receive help. Educators and administrators used the terms "extra help" and "additional help" repeatedly when describing the resource room. Elementary teachers used the term "tutoring" more often than junior high and high school teachers. Two junior high and high school teachers noted the value of the resource room as a benefit for teachers as well as students.

Only one student mentioned that the resource room was a place "for somebody to help...that can't learn as fast." No students responded that the resource room was for students with learning disabilities, IEP students or students with special needs. According to this study's student perception, an association between the resource room and disabilities was not apparent, with the exception of one student. Students viewed the room as a place where students in general may receive help. However, many educators and administrators clearly identified the resource room as a place to accommodate students with IEPs. Some educators also indicated that the resource room assisted students that did not have an IEP but had an identifiable weak area and needed extra assistance.

Why do you think you come to the resource room? Only one student indicated that she went to the resource room because she had an IEP even though all students 
interviewed had an IEP or were eligible for an IEP. This further strengthens the idea that the majority of students do not associate going to the resource room with having a disability. Educators and administrators noted that the resource room was for students showing a discrepancy in ability and performance or specifically mentioned an IEP as a reason to go the resource room. However, not all educators or administrators listed an IEP or a disability as a requirement. Many felt that students went to the resource room to receive additional help and did not require an IEP.

The majority of students indicated that receiving help was the main reason they went to the resource room. There was a slight difference in answers between elementary and junior high and high school students regarding the nature of the help. Elementary students may not fully comprehend all of the help received in the resource room. Only one elementary student clearly stated that she came to receive help. Students required much prompting in order to express that they went to the resource room for subjects such as math, reading, science, language and spelling. Most elementary student responses were vague, and it was difficult for students to think of the areas in which they were receiving help. Four out of five elementary students admitted they came to take tests and quizzes. Two of these students stated that it was the only help they received in the resource room. One indicated that she took her tests there because it was quiet. One student stated he went because his teacher told him to take his tests there. Neither student acknowledged a personal need for taking the test in the resource room. No other elementary students clearly identified that they were weak in a subject area and in need of assistance.

In contrast, the junior high and high school students were able to specifically identify subject areas in which they received help. Most students' initial response was 
that they received help. When prompted as to what subject areas, junior high and high school students were quick to list the exact subject where they needed assistance. One student did not admit a personal need for help. He indicated that he attended the resource room because his parents and teachers thought that he should. These findings imply that age may also be a factor in understanding not only the purpose but also recognition of a personal need for the resource room.

All teachers and administrators listed getting help as a main reason students attend the resource room. Their answers also included "learning skills and strategies" as well as to "better understand the material from the regular classroom". A common phrase was "individualized" in regard to assistance indicating that teachers felt that personal assistance was a reason students attended the resource room. No students mentioned they went to learn strategies or skills in order to better succeed in the general classroom. They also did not indicate that individualized instruction was a reason they attended the resource room. One elementary teacher noted that the resource room may be for remedial work or additional practice. Tests and quizzes were a category of help indicated by all teachers and administrators. Teachers and administrators were able to more clearly express that the purpose of the resource room was to receive individualized help, give assistance with tests and quizzes and learn skills and strategies to better succeed in the general classroom.

What are the benefits of the resource room? This question also posed a challenge for a few elementary students. It was difficult for some students to express what they liked about the resource room. Answers such as "I don't know," "It's awesome," and "anything really" were broad answers without much depth. Even with prompting some 
students were still not able to identify what they liked or the benefits of the resource room. These students did not indicate they perceived no benefits. All appeared to like the resource room. However, they were unable to clearly identify or express the benefits they perceived. This may be due to the type and nature of their particular disability as well as age. Junior high and high school students were able to clearly identify the benefits they perceived.

Other elementary students were able to list two benefits of the resource room: help with work and the quiet environment. Junior high and high school students agreed that help with work was a benefit and also added the value of the resource teacher. Elementary students commented that the resource teacher helped them by reading or writing the answers for them. Junior high and high school students responded that the benefit of the help received was that they were better able to understand their school work. Younger students indicated that the resource teacher helped them do their work. Older students indicated that the resource teacher helped them understand their work. This mimics the natural learning process as younger students often need more assistance completing tasks. More independence is required of older students, therefore, the resource teacher helps them better understand so they are able to do the work on their own.

The quiet environment was noted by two elementary students as a benefit. These students enjoyed the quiet atmosphere allowing them the ability to concentrate further. The junior high and high school students may not have noted the quietness of the room due to the flexibility of the schedule. All of the junior high and high school students currently attending the resource room stated they go to the resource room "when I need 
help". Since their purpose is to receive help and it is not a daily set time, they may not directly perceive the quiet environment as a benefit. Older students appear to value the independence and flexibility of the schedule.

Two junior high and high school students commented that the resource room teacher was a benefit. They described her characteristics as being willing to help, nice and funny. Although more of the elementary and junior high and high school students did not comment on the resource room teacher, no students commented negatively about her.

One high school student saw no benefits in the resource room. He expressed that he felt he did not need to attend the resource room and when he did the help he received was not a benefit.

The benefits perceived by the students were the value of help, a quiet environment and the resource room teacher. These same benefits were noted by educators and administrators creating a school-wide consensus on this issue. A major portion of the surveys described the assistance given to students as "one on one," "individualized," and “extra help." Overwhelmingly educators and administrators felt that the value of the resource room was the personal assistance given to students. All agreed that the quiet environment was a major benefit. Words such as "non-threatening," "private space," and "quiet" were used frequently to describe the environment.

The value of the resource teacher was expressed in three different ways. First, the resource teacher was seen as a means to assist general teachers in meeting the needs of every student in their class. Teachers commented that the resource teacher is specially trained to define the needs of each student so that the school is able to better serve them. 
The final comment noted the resource room teacher exhibited qualities of gentleness mixed with a boldness of motivation as well as a willingness to take teachers' input.

What are the limitations of the resource room? The perceived limitations of the resource room were few and could be corrected with a few changes. Two elementary students and three junior high and high school students did not give any limitations of the resource room. The common response was "nothing" when asked what the limitations were. Even with a slight wording change as to what they did not like about the resource room the students still responded that there were no perceived limitations. Half of all students interviewed did not perceive a limitation. The other half varied in their responses and opinions.

One elementary student commented that the resource room was often noisy due to its close proximity to the junior high and high school students and the noise of changing classes. This limitation can easily be corrected by moving the resource room to a quieter location in order to preserve the quiet atmosphere that students and teachers noted as a benefit.

Two elementary students wanted a change in help. Two students wanted to stay in the classroom to take their tests. Although students may express that they do not want to take tests in the resource room, special consideration must be given to determine if this is necessary despite their feelings. Elementary students may not understand that taking tests in the resource room is in their best interest.

One junior high and high school student commented that he could not focus in the resource room, but he admitted he could not focus in the general classroom either. He was unable to identify the source of the distraction in the resource room. 
Another student felt that the resource room was a waste of time. He did not want to receive help and did not feel that he needed help. He felt the help he received, such as reading questions to him, was something he could do on his own and only slowed him down in finishing his homework. He no longer attends the resource room. It is important to note that this particular student may be in denial of having a disability. The purpose of this study was to listen to the voices of the students in order to understand their perceptions of the resource room. This negative perception of the resource room could be minimized by listening to the student and balancing the nature of his needs with his wants.

One student explained that she was embarrassed when in front of everyone in study hall the resource teacher would ask her if she needed help. This limitation can easily be addressed by talking with the resource teacher and alerting her to the matter. The resource teacher may then find a convenient, less embarrassing time to conference with that student.

Another student noted that the only limitation was having to catch up on school work missed while in the resource room. This could easily be corrected by careful planning, scheduling and conferencing with the general classroom teacher in order to facilitate smooth transitions.

Leaving the classroom was not perceived as a limitation of the resource room. Students did not associate stigmas, labels or embarrassment with leaving the general classroom. One student indicated it bothered him a little but when questioned further could not express any ideas as to what could be done to make it easier. One student had never considered whether or not leaving bothered her before. One administrator did 
mention labels as a possible limitation of the resource room. However, most students immediately replied that it did not bother them indicating that taking them out of the general classroom did not negatively impact their self-esteem.

Educators and administrators perceived different limitations than students did. In general, educators and administrators agreed that there were time constraints, a need for a full time resource room teacher or an additional resource teacher, and limitations in the physical environment.

Both elementary and junior high and high school teachers felt that time constraints were a problem, although they had slightly different views of the time restraints. A major concern from the elementary teachers was scheduling conflicts. Elementary teachers noted that students could not always be taken during the subject needing intervention. This created problems in releasing the student in the middle of a subject and catching up the student on missed work. Elementary teachers also stated that special events often took preeminence over resource room time. Junior high and high school teachers felt most strongly that the amount of time available per student was limited, especially since the resource room was shared by the elementary. They felt that there were too many students and too many time limitations. One administrator summed it up by saying there is only one person to help K-12 students in the resource room.

A full time or additional teacher would ease the time constraints of sharing the resource room and provide greater scheduling opportunities. However, lack of a full time teacher was also noted as one of the limitations of the resource room. This was most strongly expressed from junior high and high school teachers. They also had the most concerns regarding the number of students and the limited amount of time. One 
elementary teacher and administrator echoed the concerns for a full time or additional teacher. Having a full time or additional teacher would solve both the problem of time constraints as well as having a teacher available to adequately meet the needs of students.

The physical environment was also an area of concern from both teachers and administrators. Teachers commented that it was "not a real room" as it was also shared with the art room. Teachers described the room as small, used for other storage needs and had long cafeteria tables with uncomfortable seats. It was also noted that the whiteboard did not clean up properly, preventing a clear surface for the resource teacher to use in teaching. Elementary teachers requested more manipulatives for the resource room as well as storage room for the manipulatives. Posters for math or phonics were also suggested. As a small private school limited in space, finding a room specially designated for the resource room may be difficult. However, purchasing more comfortable desks, chairs and resources would enhance the resource room.

What are some improvements that could be made? Some students indicated that they liked the room the way it was and did not see anything to change. When questioned further some desired to change minor parts of the resource room. Four out of ten students responded that they would like to change some aspect of the physical environment. Two students wanted to paint the walls in their favorite colors. This showed that the students desired to take ownership of the classroom and make it personal. One student wanted a bigger classroom so that he could have more people go to the resource room. He did not find any limitations in the resource room, but rather want to have more people experience it. Another student wanted the resource room to be moved to the original spot because it was quieter and more comfortable there. Within reason, accommodations could be made 
to make the physical appearance of the classroom more pleasing to the eye and comfortable.

These concerns were also addressed by teachers in their comments on limitations. However, teachers focused more on chairs, desks, computers and technology with more resources. Teachers and administrators also agreed that the resource room should have its own space. Suggestions for a larger more centrally located room were also given. One teacher suggested asking the resource room teacher what she needed and then doing everything possible to get the requested items. One teacher stated there needed to be a change in additional funding. This appears to be the major setback regarding changes in the physical location of the resource room. It may not be possible to add a bigger room or designate a room only for the resource room due to the limited space of a small private school. Combining the requests of teachers, students and the resource room teacher would be the best course of action regarding the changing of the physical environment. The resource room could then be redesigned to be comfortable and quiet with plenty of room and adequate resources even if a larger separate room were not possible.

Three students desired to see a change in how they received help. One elementary student wanted to do more subjects in the resource room because she felt they were going to be easier indicating that the resource teacher was helping to lighten her academic load by assisting her with school work. Two junior high and high school students desired to be more independent. One wanted to try the work on his own first and then go to the resource room if necessary. He felt that he was capable of doing most of the work and wanted to be more independent. Another student did not want help from the resource teacher and wished that someone would have asked him if he wanted help 
and in what subject areas. Independence seemed to be a common theme among junior high and high school students. They desired flexibility in going to the resource room only when needed. This indicated academic growth. Rather than relying on the resource room like a crutch, these students wanted to take more control of their learning.

As mentioned in the limitations of the resource room, teachers and administrators suggested a full time or additional teacher as an improvement. All educators and administrators were in agreement on this issue. Suggestions for servicing more students as well as having flexible schedules were also included. One administrator implied that adding another teacher or hiring a full time teacher was not currently feasible due to financial restrictions.

Both elementary and junior high and high school teachers requested to conference with the resource room teacher more often. One administrator desired the resource teacher to provide placement testing for new students. Setting up short conference times with the resource room teacher each quarter would provide more communication for teachers. Scheduling placement testing for new students with the resource room teacher would also provide for a smoother transition for new students.

\section{Potential Applications of the Findings}

Carefully consider the purpose and potential of the resource room. Educators and administrators need to carefully consider the purpose of the resource room in order to best service the needs of the students. The main purpose of the resource room in a small private school is to service students on an IEP as mandated by law. However, the purpose and potential of the resource room may extend beyond servicing only IEP students. Teacher comments revealed an inconsistency as to who was able to be serviced 
in the resource room. Some teachers reported only students with IEPs, and others reported that students without IEPs were serviced. Educators and administrators must reach a consensus on this issue. Should the resource room service only IEP students or include other students that need academic assistance as well? The answer to this question may determine the size of the room, the number of teachers needed, and the necessary resources for proper operation. Teachers and administrators continually used phrases such as "one on one help," "individualized instruction," and "extra help" to describe the purpose of the resource room. If the school is financially unable to support additional students, then limiting the resource room to only IEP students may be wise. However, if possible, the resource room may be used as a tutoring room or an area where struggling students may receive help as well. Many teachers commented that they would like to see more students serviced. Determining the purpose of the resource room and carefully considering the financial aspects involved will classify the students that are able to be serviced.

The purpose of the resource room may be dual in nature. One high school teacher and two elementary teachers indicated that the resource room may also be used to challenge students. Aside from servicing IEP students and struggling students, the resource room may also be used to challenge excelling students. In the same quiet, one on one atmosphere that struggling students thrive, excelling students may also thrive by receiving personalized instruction challenging them academically. Careful consideration must be given to ensure that IEP students do receive priority as mandated by law and that adequate resources are available to service both groups of students. This may give 
needed justification for a separate room in a small private school if the resource room is able to service a larger number of students.

The resource room may also service teachers as well as students. Two junior high and high school teachers commented that it was a resource for them. This idea must also be carefully considered. Additional resources may be housed in the resource room that teachers may use as needed. Teachers suggested setting up conference times to meet with the resource room teacher regarding their students. The resource room may also be used as a conference area. This would need to be scheduled accordingly but would provide the general teacher with a wealth of information as to how best meet the needs of her students. The resource teacher is a resource herself by arming the general teacher with strategies to be used in the general classroom. The resource room teacher may even recommend materials available in the resource room in order to enable the general teacher to meet that need effectively. However, teachers need to know that the resource teacher is available for conferencing and resources are available for teachers to use. It is important to carefully consider the possibilities and potential of the resource room along with financial aspects in order to ensure that the maximum number of students is able to be serviced effectively.

Explain the purpose of the resource room to students. Once the purpose of the resource room has been determined, students attending the resource room need to be informed as well. Four out of five elementary students in this study stated the resource room was the art room. One student recognized it as a place to receive help. The answers were reversed in the junior high and high school. One student commented it was the art room. The rest of the students indicated it was a place to receive help. 
Elementary students may not clearly understand why they attend the resource room. According to this study, the older students better understood the purpose of the resource room. This was also evident in student responses as to why they came to the resource room. Elementary students seemed to struggle listing subject areas where they received help. Junior high and high school students were able to quickly identify the areas of weakness in which they needed assistance. One student's comment was that he went to the resource room because he was told to by his teacher. The resource room should been seen as place to receive extra help, or additional assistance, and its purpose should be clear to students as well. One student commented that the resource room was for students that can't learn as fast. Another said she went to the resource room because she was on an IEP. There should be no embarrassment in explaining the purpose of the resource room to the students. However, simply explaining that the resource teacher is going to give one on one help in order to help students achieve their best is necessary. Careful consideration must be given when explaining weak areas to a student so that the student does not feel defined or confined by a label. Labels are not necessary in explaining that the resource room is a place where a student can receive help in order to do his best. Instead one should emphasis the unique gifts and abilities of that student. However, a student should be aware of weaknesses in order to work effectively on strengthening them. If a student does not understand why he attends the resource room, feelings of misunderstanding and confusion may grow, possibly leading to resentment over time. If students understand that they attend the resource room in order to help them achieve their best, this fosters a positive relationship. Students that may attend the resource room for the accelerated program need to be informed as well. 
Schedule the resource room to best meet the needs of the students. Teachers commented that scheduling conflicts were a limitation of the resource room. The junior high and high school teachers indicated that they did not like sharing with the elementary. The elementary indicated that they did not like being pre-empted from the room for other activities. Educators and administrators must conference together in order to determine the best schedule for everyone. Elementary teachers also noted that students were pulled out in different subjects than the ones in which they needed assistance. One elementary student commented that she did not mind going to the resource room except when she got behind in the general classroom and had to catch up on her work. If the purpose of the resource room is to help the student achieve his best, then it cannot create more problems for the student when he leaves the classroom. The administration needs to carefully consider the number of teachers needed to adequately service the students as well as avoiding scheduling conflicts. If additional teachers are not financially feasible, then an arrangement that best meets the needs of the students must be worked out. The majority of students indicated that the main benefit of the resource room was the help they received. The resource room must be given priority over other events that may take place in the room in order to ensure this benefit to all students.

Create a conducive learning environment. In order to best meet the needs of students, the resource room must provide a comfortable environment in which students are able to learn. Perhaps the first consideration of the resource room should be a separate room designated only as the resource room. This was a suggestion made by teachers as the current room in this study was shared with the art room. The purpose of the resource 
room may be thwarted if the resource room is not adequately meeting the needs of the students.

The location of the resource room is also of primary importance. In a school where the resource room is shared by elementary and junior high and high school students, a central location should be established if possible. In addition, the room should be of adequate size in proportion to the number of students attending and should have plenty of storage space for resources. This suggestion was given by teachers as they desired to see the resource teacher able to have adequate supplies to use, as well as be able to use materials as a resource for the general classroom. In determining the best location for the resource room, one must ensure that the room is able to maintain the quiet atmosphere that students and teachers noted as a benefit. Students commented that they were able to concentrate better in the quiet environment. Teachers added that the resource room minimized distractions and provided a more relaxing environment. One student mentioned that the changing of classes near the resource room disrupted the quietness of the room. One must also consider the area surrounding the resource room in order to determine if the quiet atmosphere is able to be maintained both inside and outside the room.

The correct furniture in the resource room will also foster a learning environment. Many teachers and administrators suggested that the resource room have desks and chairs instead of the long cafeteria tables that are currently in the resource room. The resource room should be given the best resources available instead of whatever may be available or is left over after meeting other needs. Keeping the resource room similar to the general classroom may also make the transition between the general classroom and the 
resource room smoother. Students will feel as comfortable in this environment as they did in their general classroom.

Integrate technology. The resource room must be technologically current. In a technical world, students must have access to technology. One cannot hope to assist students in achieving their best if they are lagging behind in technology. Careful consideration should be given to the necessary forms of technology. If the resource room only services one or two students at a time, then a large quantity of computers would not be needed. Neither would a Smartboard if each student were able to use a personal computer to learn. Understanding what technology is needed and in what quantity may help to reduce the financial burden. Technology can be used for remedial practice as well as to challenge excelling students. Its dual purpose in supporting both groups of students makes it a valuable component in the resource room. The internet also provides a network of materials that can be utilized instantly by the resource teacher in order assist a student struggling in a particular area. This enhances the learning process and enables the student to receive instruction in a different mode than normally used. Students may have different technological needs. Careful consideration must be given to ensure that the needs of each student are met.

Foster independence. The structure of the resource room should be designed in order to enable students to be more independent. Elementary students in this study often had set schedules in which they visited the resource room. The majority of junior high and high school students indicated that they could come and go to the resource room as needed. Two students desired to have more control over the process and valued independence. The resource room should be more structured for the younger students as 
they are building skills and strategies in order to gain independence. The resource room should be more flexible to best meet the needs of older students. By allowing students to take charge of their learning, students will not use the resource room as a crutch. Rather, they begin to put into practice the skills they were taught in order to become as academically independent at possible. However, the resource room teacher should still conference with older students regarding academics on a weekly basis to ensure that each student is successful and provide assistance as needed. One junior high and high school student indicated that the resource room teacher often contacted her during study hall in front of her friends and embarrassed her. Having a set time to conference weekly without embarrassing the student would enable students to keep their independence but also hold them accountable.

Hire an appropriate number of teachers. Both teachers and administrators commented on the need for a full time resource room teacher or an additional teacher. Although this was a small private school servicing only twelve students, a part time resource teacher was not enough. Administrators must take into account the purpose of the resource room as well as the number of students attending in order to determine if more than one teacher is necessary. Priority must be given to allocating funding to have the necessary staff to meet the needs of students. The resource room teacher should be a trained and qualified specialist. This ensures that the teacher is knowledgeable in a variety of disabilities and learning needs students might have and is able to address their needs appropriately. 


\section{Biblical Integration}

Christian educators must live in light of God's Word. We must see each student as God sees him, a special part of His creation. Genesis 1:27 tells us, "God created man in his own image, in the image of God he created him; male and female he created them." Every student is created in the image of God including students with disabilities. As Christian educators we must be careful to view students with disabilities as whole students and recognize they have been made in His image (Anderson, 2003). God knew each person before he was born. God specially created us to be exactly who He wanted us to be. He does not make mistakes or accidents. Each child is fearfully and wonderfully made. Psalm 139:13-14 points out, "For you created me in my inmost being; you knit me together in my mother's womb. I praise you because I am fearfully and wonderfully made; your works are wonderful, I know that full well." Therefore, we must view each child as a child of God, created in His image according to His plan.

As Christian educators living in light of God's truth, we must consider how we teach students with disabilities. One only has to look at the history of special education to realize that students with disabilities have been excluded more often than they have been included. We must make every effort to include those who have been excluded. This was the heart of Jesus' ministry as well (Anderson, 2003).

First, students with disabilities cannot be left out of the general curriculum. Although they may learn in a different manner or require more assistance, every effort must be made to provide access to the general curriculum. Therefore, the resource room must be utilized to help students with disabilities meet their full potential. As a teacher, I need to be aware of and understand the special needs of my students so that I am able to 
assist them in achieving their potential. Conferencing with the resource room teacher in order to ensure that the student's needs are being met in the general classroom is a necessary component. I cannot fully serve my students if I do not understand their needs or how they learn.

Secondly, students with disabilities within the general classroom must be included and treated as class members. They cannot be part-time members that come and go, disconnected from the rest of the class. This includes scheduling appropriate times for students to leave the general classroom that correlate with the subject area in which assistance is needed. This allows the student to leave and reenter the classroom without getting behind or missing special activities that make him an outsider to the classroom.

Christian educators must also set an active example in treating students with disabilities with dignity and respect. There is no place for favoritism in the life of a Christian. Children pick up actions more than words spoken. Therefore, I must carefully watch my words and actions to make sure they are Christ-like. It is easy to get frustrated or upset when learning takes longer than expected or a student does not understand the lesson. It is equally as easy to take my frustrations out on the student instead of using the frustration to solve the problem. Each student in my classroom must feel loved and valued as a treasure of God. Instead of pointing out the negative aspects of disabilities, emphasis must be placed on the gifts and abilities God has given each student (Nouwen, 1988). He has created each student unique and special. I Peter 4:10 says, "God has given each of you some special abilities; be sure to use them to help each other." Without singling out students with disabilities, I must help students understand that we all have weaknesses just as we all have strengths. We were created to be interdependent. In the 
classroom this fosters team building and membership as each student brings his gifts to be used to encourage and lift up other class members. As each student realizes he has a gift to be used, he begins to understand his value in the classroom and his value in the sight of God.

The resource room is merely a tool available to assist students in achieving their potential. The goal of a Christian educator is twofold. It is helping students realize God has given them a gift and assisting them in discovering what that gift is and how to use it for His glory.

\section{Relation of the Results to Literature}

Previous literature on the resource room enhances and further illustrates the findings of this present study. Students in the present study were asked what the resource room was and why they went there. Most of the elementary students responded that the resource room was the art room but were able to clearly express that they went to the resource room to receive help. The junior high and high school students overwhelmingly indicated that the resource room was a place to receive help and that they went there to receive that help. Similar results were found in a study by Vaughn and Bos (1987). The study found that students thought the resource room was a place for special help or to learn better. It was a place to do work, testing, and was quiet. Students in the current study were able to list subject areas in which they received help and reported that they took tests and quizzes in the room. They also indicated the quietness of the room was a reason they came. Junior high and high school students especially noted that the resource room teacher helped them learn the material and understand it better. 
Albinger (1995) reported that students often do not know why they go to the resource room. They know they need assistance but do not understand they have a specific learning disability. Albinger stated that students could explain what subject areas they had difficulty in but could not explain what their difficulties were. Elementary students in this study had to be prompted to list some of the areas in which they received help. However, most junior high and high school students indicated almost immediately what subjects gave them problems. Two students could identify their disabilities. One student said she could not read and comprehend well. The other student said he had trouble concentrating. Like the students in Albinger's study, most students in this study were unable to clearly express why they had difficulty learning. This could be due to the nature of the question or to the lack of understanding personal deficiencies. In addition, Albinger (1995) reported that students knew the resource room was a place to receive help but not all students knew it was part of a special educational program because of their special education label. Similarly, students in the current study indicated that the resource room was for students that need help. Only one student said it was for students "who can't learn as fast". Vaughn and Bos (1987) found that when students were given open-ended questions, they did not imply that the resource room was for students that were not as bright. The rest of the students in the present study seemed to imply that the resource room was open to all students. The comments of teachers and administrators were mixed. Some believe the resource room was for only students with an IEP, and others believed it serviced both.

Kauffman and Pullen (1996) highlighted the assumption that one naturally assumes that being separate from the majority is always negative. Will (1986) noted 
stigmas as a major criticism of resource rooms. This is not always the case as was clearly demonstrated in this study. The majority of students in this study expressed that leaving the regular classroom to attend the resource room did not bother them. One student indicated that it bothered him but could not make any suggestions for fixing it when questioned further. Two students appeared to be unsure and had never considered it before. The majority of students immediately indicated that leaving the general classroom was not embarrassing to them. This contrasted with the findings by Albinger (1995). Albinger found that elementary students with learning disabilities reported leaving the regular classroom as embarrassing. Whinnery and King (1995) asserted that students with learning disabilities in resource rooms tend to feel dumb, made fun of, left out and embarrassed. This was not indicated by the elementary and junior high and high school students that participated in this study.

Rather the findings of this study coincide with the study by Vaughn and Klingner (1998). Vaughn and Klingner cited four positive reasons that students enjoy the resource room. They reported that students enjoy the resource room due to the additional help, exciting activities, lessened work load, and the ability to work in a quiet setting. Padeliadu and Zigmond (1996) reported that the students in their studies expressed that the resource room was a quiet place where they could focus and receive extra help. In the current study, students clearly indicated that the additional help was a benefit of the resource room. A few students also mentioned the quiet setting and lessened work load as benefits. Students of the current study felt that the resource room teacher helped them with their work and to achieve better grades. Whinnery and King (1995) reported that students with learning disabilities regardless of placement agreed that the special 
education teacher helped them achieve better grades. Teachers and administrators commented on the specialized training that the resource room teacher received and how it benefitted the students.

One student in the present study expressed concern over the disruption of class instruction and felt that general class work was missed and had to be caught up upon her return. Similarly, the students in a study by Padeliadu and Zigmond (1996) expressed anxiety over both academic and recreational activities they missed while they were in the resource room. Albinger (1995) also reported that students were worried about the amount of work that would have to be made up from their absence.

Teachers in the current study also commented on the disruptions of class instruction. Wang, Reynolds, and Walberg (1987) noted that a major criticism of the resource room was the disruption of learning in the general classroom. Comments of the teachers and administrators in this present study echoed Sailor and Roger (2005) who stated that the main problem with placement is often schedules, available teachers and space. In both limitations and suggestions for improvements, teachers of the current study listed scheduling conflicts, the need for an additional or full time teacher and either a more comfortable or separate space as necessary improvements. Kauffman and Pullen (1996) argued similarly that a placement is only as good as the instruction given and the instruction is only effective if the proper number of students and support available are appropriate.

\section{Strengths of the Study}

This study was designed as an action research project in a small private school. Participation by students and teachers allowed for adequate saturation. Ten out of 
thirteen students that were on an IEP or eligible for one and attended the resource room were interviewed. One student moved away. One indicated she did not want to be interviewed, and one did not return the consent form despite numerous attempted contacts. Of the ten students that did participate, five students were elementary, and five students represented the junior high and high school side. This even number allowed for the responses from elementary and junior high and high school students to be balanced. All of the teachers and administrators at the school included in the study participated allowing for saturation and accurate representation of the data. The kindergarten teacher did not participate. However, she has not sent a student to the resource room in over ten years. Since she does not play an active part in the current resource room, she was excluded from the study.

This study focused on one resource room and one resource room teacher within a small private school. The majority of previous studies did not focus on private schools and studied more than one school, resource room and teacher. Researchers have cautioned against considering all resource rooms the same (Haynes \& Jenkins, 1986). However, the benefit of this study is that all students shared their perceptions about the same resource room and teacher allowing for accurate and focused representation of the data in this action research project. The resource room teacher has served four of the ten students five years or more. A mixture of newer students and older students in the resource room allows for variety of well-rounded responses. Teachers and administrators have worked with the resource room teacher for a number of years. Therefore, their opinions reflect years of observations regarding benefits and limitations. 
The method of data collection was designed to triangulate findings by interviewing students and collecting surveys from teachers and administrators. A rich data set was achieved by interviewing ten out of thirteen eligible students and all teachers and administrators with students actively using the resource room. Interviews were transcribed and coded for common themes. Surveys followed a similar process of coding. Both teachers and students were asked the same questions in order to compare the data sets. The use of low inference descriptors in the presentation of the findings accurately portrayed the voice of the students, teachers and administrators. Conscious effort was made to include as many responses from students, teachers and administrators as possible. In order to offset researcher bias I reflected on my predispositions during interviews. I purposely questioned the students to determine if leaving the general classroom bothered or embarrassed them. I actively sought negative case sampling and included it in both the student and teacher data.

\section{Limitations of the Study}

Remaining threats to internal validity. Although interviews provide a rich data set, the breadth and depth of answers are not always the same. Some students provided in-depth answers, and others gave only cursory responses. The range of disabilities may also have affected how much a student understood and how adequately they were able to express themselves verbally. Even after prompting some students still responded with one word answers or said, "I don’t know." The purpose of this study was not to determine differences in disabilities but to examine the perceptions of students attending the resource room. The number of students interviewed indicates that saturation was reached and the findings produced are viable. 
Another limitation is the inability to use random sampling in the study. Instead, convenience and purposive sample occurred based on the goals of the study. The target sample was students that were on an IEP or eligible for an IEP and attended the resource room. Therefore, no randomization could occur within the sampling. All students meeting the criteria were mailed a consent letter indicating the purpose of the study. Students matching the requirements with both parental and student consent were interviewed. In order to gain breadth in a small private school, all teachers and administrators actively using the resource room were surveyed.

The parameter of an action research project with limiting criteria for participants produced a small data set. There were five elementary students and five junior high and high school students that participated. Three students were not included in the study for varying reasons. One student moved away. One did not want to participate, and one did not return the consent form. However, fourteen teachers and four administrators were able to provide data triangulation. All teachers working with students that actively use the resource room were surveyed.

Another limitation involved my lack of training in special education. My limited knowledge of certain disabilities may have hindered my ability to prompt students according to their needs and in a way they would understand. The use of oral interviews may have limited some student answers due to their specific disability.

Remaining threats to external validity. The parameters of the study resulted in a limited, non-random population. The study took place in a small private K-12 school consisting of approximately 170 students and limits the study to broad generalization to all schools. One Multi-racial and nine Caucasian students composed the study group. 
The small number of students as well their composition restricts generalization to all schools. Although the results cannot be generalized to all schools, they may be applicable to small, private schools with a similar population. However, the findings of this study are beneficial in adding to the community of voices regarding student perception of the resource room.

\section{Suggestions for Future Research}

This study could be expanded to include a variety of future study options. Studying a large private school or comparing results from more than one private school would broaden the depth of data collection. Comparing the perceptions of students attending the resource room in private and public schools would provide a rich data set. Future research needs to be collected on the perceptions of the resource room from students without disabilities in private schools.

This study only focused on the qualitative aspect of the resource room. Quantitative studies on the resource room also need to be conducted on private schools. Many private schools are left out of the traditional studies done on the resource room. However, the resource room is often the only service model available in these schools. Analyzing data on students with and without disabilities in the resource room would provide further understanding of the data collected in this study.

Future studies on the involvement of students in placement options in both private and public schools should also be studied. Studying the relationship between student involvement and the perceived benefits and limitations of the service model should be conducted. This may lead to further studies on the self-concept of students and their involvement in the placement process. 
Future research should focus on parents that have students attending a resource room in a private school. Parents should be surveyed or interviewed regarding their knowledge and perceptions of the resource room. Data triangulation would be strengthened in comparing parent, teacher, administrator and student perceptions. Analysis of this data would allow educators and parents to partner together in strengthening the benefits and modifying the limitations of the resource room to better meet student needs. 


\section{REFERENCES}

Affleck, J. Q., Madge, S., Adams, A., \& Lowenbraun, S. (1988). Integrated classroom versus resource model: Academic viability and effectiveness. Exceptional Children, 54(4), 339-348.

Albinger, P. (1995). Stories from the resource room: Piano lessons, imaginary illness, and broken-down cars. Journal of Learning Disabilities, 28(10), 615-621.

Anderson, D. W. (2003). Special education as reconciliation. Journal of Education \& Christian Belief, 7(1), 23.

Anderson-Inman, L. (1986). Bridging the gap: Student-centered strategies for promoting the transfer of learning. Exceptional Children, 52(6), 562-572.

Bauwens, J., \& Hourcade, J. (1991). Making co-teaching a mainstreaming strategy. Preventing School Failure, 35, 19-24.

Bauwens, J., Hourcade, J. J., \& Friend, M. (1989). Cooperative teaching: A model for general and special education integration. Remedial and Special Education, 10(2), $17-22$ 
Bear, G. G., \& Minke, K. M. (1996). Positive bias in maintenance of self-worth among children with LD. Learning Disability Quarterly, 19, 23-32.

Bear, G. G., Clever, A., \& Proctor, W. A. (1991). Self-perceptions of non-handicapped children and children with learning disabilities in integrated classes. The Journal of Special Education, 24(4), 409-426.

Bear, G. G., Minke, K. M., \& Manning, M. A. (2002). Self-concept of students with learning disabilities: A meta-analysis. School Psychology Review, 31(3), 405-427.

Biklen, D., \& Zollers, N. (1986). The focus of advocacy in the LD field. Journal of Learning Disabilities, 19(10), 579-586.

Blanton, L. P., Blanton, W. E., \& Cross, L. S. (1994). An exploratory study of how general and special education teachers think and make instructional decisions about students with special needs. Teacher Education and Special Education, 17(1), 62-74.

Capper, C. A., \& Pickett, R. S. (1994). The relationship between school structure and culture and student views of diversity and inclusive education. The Special Education Leadership Review, 2, 102-122.

Carlberg, C., \& Kavale, K. (1980). The efficacy of special versus regular class placements for exceptional children: A meta-analysis. Journal of Special Education, 14, 295-309.

Chapman, J. W. (1988). Learning disabled children's self-concepts. Review of Educational Research, 58(3), 347-371. 
Cohen, J. (1985). Learning disabilities and adolescence: Developmental considerations. Adolescent Psychiatry, 12, 177-196.

Coleman, J. M. (1983). Self-concept and the mildly handicapped: The role of social comparisons. The Journal of Special Education, 17, 37-45.

Conley, T. D., Ghavami, N., VonOhlen, J., \& Foulkes, P. (2007). General and domainspecific self-esteem among regular education and special education students. Journal of Applied Social Psychology, 37(4), 775-789.

Cooley, E. J., \& Ayres, R. R. (1988). Self-concept and success-failure attributions of nonhandicapped students and students with learning disabilities. Journal of Learning Disabilities, 21(3), 174-178.

Cooper, S., \& Bailey, N. M. (2001). Psychiatric disorders amongst adults with a learning disability - prevalence and relationship to ability. Irish Journal of Psychological Medicine, 18(2), 45-53.

Crocker, J., \& Major, B. (1989). Social stigma and self-esteem: The self-protective properties of stigma. Psychological Review, 96(4), 608-630.

Cuban, L. (1989). The "at-risk" label and the problem of urban education reform. Phi Delta Kappan, 70, 780-784, 799-801.

Daane, C. J., Beirne-Smith, M., \& Latham, D. (2000). Administrators' and teachers' perceptions of the collaborative efforts of inclusion in the elementary grades. Education, 121(2), 331-338. 
Damon, W. H. (1996). Greater expectations: Overcoming the culture of indulgence in our schools. New York: Free Press.

Davis, J. A. (1966). The campus as a frog pond: An application of the theory of relative deprivation to career decisions of college men. American Journal of Sociology, 72, $17-31$.

DeFrancesco, J. J., \& Taylor, J. (1985). Dimensions of self-concept in primary and middle school learning disabled and nondisabled students. Child Study Journal, 15(2), 99-105.

Deno, E. (1970). Special education as developmental capital. Exceptional Children, 37, 229-237.

Deno, S., Maruyama, G., Espin, C., \& Cohen, C. (1990). Educating students with mild disabilities in general education classrooms: Minnesota alternatives. Exceptional Children, 57(2), 150-161.

Eigenbrood, R. (2005). A survey comparing special education services for students with disabilities in rural faith-based and public school settings. Remedial \& Special Education, 26(1), 16-24.

Elbaum, B., \& Vaughn, S. (2003). Self-concept and students with learning disabilities. In H. L. Swanson, K. R. Harris \& S. Graham (Eds.), Handbook of learning disabilities (pp. 229-241). New York: Guilford Press. 
Elbaum, B. (2002). The self-concept of students with learning disabilities: A metaanalysis of comparisons across different placements. Learning Disabilities Research \& Practice, 17(4), 216-226.

Ericson, D. P., \& Ellett, F. J. (1990). What can research on teacher thinking contribute to teacher preparation? A second opinion. Educational Researcher, 19(9), 3-10.

Erikson, E. H. (1959). Identity and the life cycle. Psychological Issues, 1, 18-164.

Espin, C. A., Deno, S. L., \& Albayrak-Kaymak, D. (1998). Individualized education programs in resource and inclusive settings: How "individualized" are they? The Journal of Special Education, 32(3), 164-174.

Etscheidt, S. (2006). Least restrictive and natural environments for young children with disabilities: A legal analysis of issues. Topics in Early Childhood Special Education, 26(3), 167-178.

Festinger, L. (1954). A theory of social comparison processes. Human Relations, 7, 117140.

Forman, E. A. (1988). The effects of social support and school placement on the selfconcept of LD students. Learning Disability Quarterly, 11(2), 115-124.

Friend, M., \& Bursuck, W. D. (2006). Including students with special needs: A practical guide for classroom teachers (4th ed.). Boston: Allyn \& Bacon. 
Friend, M., \& McNutt, G. (1984). Resource room programs: Where are we now? Exceptional Children, 51(2), 150-155.

Fryxell, D., \& Kennedy, C. H. (1995). Placement along the continuum of services and its impact on students' social relationships. Journal of the Association for Persons with Severe Handicaps, 20(4), 259-269.

Fuchs, D., Fuchs, L. S., \& Fernstrom, P. (1993). A conservative approach to special education reform: Mainstreaming through transenvironmental programming and curriculum-based measurement. American Educational Research Journal, 30(1), 149-177.

Gans, A. M., Kenny, M. C., \& Ghany, D. L. (2003). Comparing the self-concept of students with and without learning disabilities. Journal of Learning Disabilities, 36(3), 287-295.

Gartner, A., \& Lipsky, D. K. (1987). Beyond special education: Toward a quality system for all students. Harvard Educational Review, 57(4), 367-395.

Garvar-Pinhas, A., \& Pedhazur-Schmelkin, L. (1989). Administrators' and teachers' attitudes toward mainstreaming. Remedial and Special Education, 10, 38-43.

Good, T. L. (1982). How teachers' expectations affect results. American Education, 18(10), 25-32.

Goodlad, J. (1984). A place called school. New York: McGraw-Hill. 
Gresham, F. M., \& MacMillan, D. L. (1997). Social competence and affective characteristics of students with mild disabilities. Review of Educational Research, $67,377-415$.

Grolnick, W. S., \& Ryan, R. M. (1990). Self-perceptions, motivation, and adjustment in children with learning disabilities: A multiple group comparison study. Journal of Learning Disabilities, 23(3), 177-184.

Haager, D., \& Vaughn, S. (1997). Assessment of social competence in students with learning disabilities. In J. W. Lloyd, E. J. Kameenui \& D. Chard (Eds.), Issues in educating students with disabilities (pp. 129-152). Mahwah, NJ: Erlbaum.

Handler, B. R. (2007). Who's in the classroom down the hall?: An examination of demographic shifts within segregated special education classrooms, 1975-2005. American Educational History Journal, 34(2), 379-393.

Haynes, M. C., \& Jenkins, J. R. (1986). Reading instruction in special education resource rooms. American Educational Research Journal, 23(2), 161-190.

Hendrickson, J. M., Shokoohi-Yekta, M., Hamre-Nietupski, S., \& Gable, R. A. (1996). Middle and high school students' perceptions on being friends with peers with severe disabilities. Exceptional Children, 63(1), 19-28.

High incidence disabilities. (2006). Retrieved April 21, 2010, from http://www.bsu.edu/web/PGPBSU/exceptionalities/phase1/high\%20incidence.html 
Hollowood, T. M., Salisbury, C., Rainforth, B., \& Palombero, M. (1994). Use of instructional time in classrooms serving students with and without severe disabilities. Exceptional Children, 61(3), 242-253.

Howard, K. A., \& Tryon, G. S. (2002). Depressive symptoms in and type of classroom placement for adolescents with LD. Journal of Learning Disabilities, 35(2), 185190.

Hunt, P., Staub, D., Alwell, M., \& Goetz, L. (1994). Achievement by all students within the context of cooperative learning groups. Journal of the Association for Persons with Severe Handicaps, 19(2), 290-301.

Idol, L. (1997). Creating collaborative and inclusive schools. Austin, TX: PRO-ED.

Idol, L., Nevin, A., \& Paolucci-Whitcomb, P. (1994). Collaborative consultation (2nd ed.). Austin, TX: PRO-ED.

Idol, L., Nevin, A., \& Paolucci-Whitcomb, P. (2000). Collaborative consultation (3rd ed.). Austin, TX: PRO-ED.

Idol, L. (2006). Toward inclusion of special education students in general education: A program evaluation of eight schools. Remedial and Special Education, 27(2), 77-94.

Individuals with Disabilities Education Improvement Act of 2004, (2004).

Jenkins, J. R., \& Heinen, A. (1989). Students' preferences for service delivery: Pull-out, in-class, or integrated models. Exceptional Children, 55(6; 6), 516-523. 
Johnston, P., Allington, R., \& Afflerbach. (1985). The congruence of classroom and remedial instruction. Elementary School Journal, 85, 465-477.

Jones, R. L. (1974). Student views of special placement and their own special classes: A clarification. Exceptional Children, 41(1), 22-29.

Kass, C. E. (1971). Introduction to learning disabilities. In D. D. Hammill, \& N. R. Bartel (Eds.), Educational perspectives in learning disabilities (pp. 3-9). New York: John Wiley \& Sons.

Kauffman, J. M., \& Pullen, P. L. (1996). Eight myths about special education. Focus on Exceptional Children, 28(5), 1-12.

Kavale, K. A., \& Forness, S. R. (2000). History, rhetoric, and reality: Analysis of the inclusion debate. Remedial \& Special Education, 21(5), 279-296.

Kirk, S. A. (1962). Educating exceptional children. Boston: Houghton Mifflin.

Kistner, J. A., \& Gatlin, D. (1989). Correlates of peer rejection among children with learning disabilities. Learning Disability Quarterly, 12(2), 133-140.

Kistner, J., Haskett, M., White, K., \& Robbins, F. (1987). Perceived competence and selfworth of LD and normally achieving students. Learning Disability Quarterly, 10(1), $37-44$.

Klingner, J. K., Vaughn, S., Schumm, J. S., Cohen, P., \& Forgan, J. W. (1998). Inclusion or pull out: Which do students prefer? Journal of Learning Disabilities, 31, 173-180. 
Kloomok, S., \& Cosden, M. (1994). Self-concept in children with learning disabilities: The relationship between global self-concept, academic "discounting," nonacademic self-concept, and perceived social support. Learning Disability Quarterly, 17, 140153.

Leondari, A. (1993). Comparability of self-concept among normal achievers, low achievers and children with learning difficulties. Educational Studies, 19(4), 357371.

Lerner, J. (1997). Learning disabilities: Theories, diagnosis, and teaching strategies (7th ed.). Boston: Houghton Mifflin.

Leyser, Y., \& Tappendorf, K. (2001). Are attitudes and practices regarding mainstreaming changing? A case of teachers in two rural school districts. Education, 121(4), 751-760.

Madden, N., \& Slavin, R. (1983). Mainstreaming students with mild handicaps: Academic and social outcomes. Review of Educational Research, 53, 519-569.

Manset, G., \& Semmel, M. I. (1997). Are inclusive programs for students with mild disabilities effective? A comparative review of model programs. The Journal of Special Education, 31(2), 155-180.

Margalit, M. (1994). Loneliness among children with special needs: Theory, research, coping, and intervention. New York: Springer Verlag. 
Markus, H. (1980). The self in thought and memory. In M. Wegner, \& R. R. Vallacher (Eds.), The self in psychology. New York: Oxford University Press.

Marston, D. (1996). A comparison of inclusion only, pull-out only, and combined service models for students with disabilities. The Journal of Special Education, 30(2), 121132.

McCoach, D. B., Kehle, T. J., Bray, M. A., \& Siegle, D. (2001). Best practices in the identification of gifted students with learning disabilities. Psychology in the Schools, $38(5), 403-411$.

McLaughlin, M. J. (1995). Defining special education: A response to zigmond and baker. Journal of Special Education, 29(2), 200-208.

Minke, K. M., Bear, G. G., Deemer, S. A., \& Griffin, S. M. (1996). Teacher experiences with inclusive classrooms: Implications for special education reform. Journal of Special Education, 30(2), 152-186.

Moore, C., Gilbreath, D., \& Maiuri, F. (1998). Educating students with disabilities in general education classrooms: A summary of the research. Washington, DC: Office of Special Education and Rehabilitative Services.

Murray-Seegert, C. (1989). Nasty girls, thugs, and humans like us: Social relations between severely disabled and nondisabled students in high school. Baltimore: Brookes. 
National Center for Educational Restructuring and Inclusion. (1995). National study of inclusion. New York: Author.

Nouwen, H. J. M. (1988). The road to daybreak: A spiritual journey. New York: Image Books/Doubleday.

Ochoa, S. H., \& Olivarez, A. (1995). A meta-analysis of peer rating socio-metric studies of pupils with learning disabilities. The Journal of Special Education, 29, 1-19.

Padeliadu, S., \& Zigmond, N. (1996). Perspectives of students with learning disabilities about special education placement. Learning Disabilities Research \& Practice, 11, $15-23$

Pavri, S., \& Monda-Amaya, L. (2000). Loneliness and students with learning disabilities in inclusive classrooms: Self-perceptions, coping strategies, and preferred interventions. Learning Disabilities Research \& Practice (Lawrence Erlbaum), 15(1), 22-33.

Peck, C. A., Donaldson, J., \& Pezzoli, M. (1990). Some benefits non-handicapped adolescents perceive for themselves from their social relationships with peers who have severe handicaps. Journal of the Association for Persons with Severe Handicaps, 15(4), 241-249.

Peck, C. A., Staub, D., Gallucci, C., \& Schwartz, I. (2004). Parent perception of the impacts of inclusion on their nondisabled child. Research and Practice for Persons with Severe Disabilities, 29(2), 135-143. 
Pelham, B. W., \& Swann, W. B. (1989). From self-conceptions to self-worth: On the sources and structure of global self-esteem. Journal of Personality and Social Psychology, 57(4), 672-680.

Phillips, L., Sapona, R. H., \& Lubic, B. (1995). Developing partnerships in inclusive education: One school's approach. Intervention in School \& Clinic, 30(5), 262-272.

Reid, D. K., \& Button, L. J. (1995). Anna's story: Narratives of personal experience about being labeled learning disabled. Journal of Learning Disabilities, 28(10), 602-614.

Renick, M. J., \& Harter, S. (1989). Impact of social comparisons on the developing selfperceptions of learning disabled students. Journal of Educational Psychology, 81(4), 631-638.

Reynolds, M. C. (1962). A framework for considering some issues in special education. Exceptional Children, 28, 367-370.

Reynolds, M. C., \& Wang, M. C. (1983). Restructuring "special" school programs: A position paper. Policy Studies Review, 2(1), 189-212.

Rosenberg, M. (1977). Contextual dissonance effects: Nature and causes. Journal for the Study of Interpersonal Processes, 40, 205-217.

Rosenberg, M. (1986). Convincing the self. Malabar, FL: Krieger.

Rosenthal, R., \& Jacobson, L. (1968). Pygmalion in the classroom: Teacher expectations and pupils' intellectual development. New York: Holt, Rinehart \& Winston. 
Ruble, D. N. (1983). The development of social comparison processes and their role in achievement-related self-socialization. In E. T. Higgins, W. W. Hartup \& D. N. Ruble (Eds.), Social cognition and social development: A sociocultural perspective. New York: Cambridge University Press.

Sabatino, D. A. (1979). A review of diagnostic and classification of antecedents in special education. In D. A. Sabatino, \& T. L. Miller (Eds.), Describing learner characteristics of handicapped children and youth. New York: Grune \& Stratton.

Sacks, A. (2001). Special education: A reference handbook. Santa Barbara, Calif.: ABCCLIO.

Sailor, W., \& Roger, B. (2005). Rethinking inclusion: Schoolwide applications. Phi Delta Kappan, 86(7), 503-509.

Sale, P., \& Carey, D. M. (1995). The sociometric status of students with disabilities in a full-inclusion school. Exceptional Children, 62(1), 6-19.

Salend, S. J. (1998). Effective mainstreaming: Creating inclusive classrooms (3rd ed.). Columbus, OH: Merrill/Prentice Hall.

Sharpe, M. N., \& York, J. L. (1994). Effects of inclusion on the academic performance of classmates without disabilities. Remedial \& Special Education, 15(5), 281-287.

Shoho, A. R., Katims, D. S., \& Wilks, D. (1997). Perceptions of alienation among students with learning disabilities in inclusive and resource settings. High School Journal, 81(1), 28-36. 
Silverman, R., \& Zigmond, N. (1983). Self-concept in learning disabled adolescents. Journal of Learning Disabilities, 16(8), 478-482.

Skrtic, T. M. (1991). Behind special education: A critical analysis of professional culture and school organization. Denver: Love Publishing.

Smelter, R. W., \& Rasch, B. W. (1994). Thinking of inclusion for all special needs students? Better think again. Phi Delta Kappan, 76(1), 35-38.

Smith, T. E. C. (2002). Section 504: What teachers need to know. Intervention in School \& Clinic, 37, 259-266.

Swick, K. J., \& Hooks, L. (2005). Parental experiences and beliefs regarding inclusive placements of their special needs children. Early Childhood Education Journal, 32(6), 397-402.

Tabassam, W., \& Grainger, J. (2002). Self-concept, attributional style and self-efficacy beliefs of students with learning disabilities with and without attention deficit hyperactivity disorder. Learning Disability Quarterly, 25(2), 141-151.

Taylor, A. R., Asher, S. R., \& Williams, G. A. (1987). The social adaptation of mainstreamed mildly retarded children. Child Development, 58(5), 1321-1334.

Thomson, R., \& McKenzie, K. (2005). What people with a learning disability understand and feel about having a learning disability. Learning Disability Practice, 8(6), 28-32. 
Turnbull, R., Turnbull, A., Shank, M., Smith, S., \& Leal, D. (2002). Exceptional lives. Special education in today's schools (3rd ed.). Upper Saddle River, New Jersey: Merill Prentice Hall.

U.S. Department of Education. (2002). Twenty-fourth annual report to congress on the implementation of the individuals with disabilities education act. Washington DC: Author.

Vaughn, S., Elbaum, B. E., \& Schumm, J. S. (1996). The effects of inclusion on the social functioning of students with learning disabilities. Journal of Learning Disabilities, 29, 598-608.

Vaughn, S., \& Bos, C. S. (1987). Knowledge and perception of the resource room: The students' perspective. Journal of Learning Disabilities, 20(4), 218-223.

Vaughn, S., Elbaum, B., \& Boardman, A. G. (2001). The social functioning of students with learning disabilities: Implications for inclusion. Exceptionality, 9(1; 1), 47-65.

Vaughn, S., \& Hogan, A. (1990). Social competence and learning disabilities: A prospective study. In H. L. Swanson, \& B. Koegh (Eds.), Learning disabilities: Theoretical and research issues (pp. 175-199). Hillsdale, NJ: Lawrence Erlbaum.

Vaughn, S., \& Klingner, J. K. (1998). Students' perceptions of inclusion and resource room settings. Journal of Special Education, 32(2), 79-88.

Vergason, G. A., \& Anderegg, M. L. (Eds.). (1997). Dictionary of special education and rehabilitation (4th ed.). Denver: Love Publishing. 
Wamba, N. G. (2008). Children with learning needs: An overview and discussion of legislative initiatives in the united states. Insights on Learning Disabilities, 5(1), 518.

Wang, M. C., \& Birch, J. (1984). Comparison of a full-time mainstreaming program and a resource room approach. Exceptional Children, 51, 33-40.

Wang, M. C., Reynolds, M. C., \& Walberg, H. J. (1987). Repairing the second system for students with special needs. Paper presented at the 1987 Wingspread Conference on The Education of Children with Special Needs: Gearing up to Meet the Challenge of the 1990s.

Whinnery, K. W., \& King, M. (1995). Perceptions of students with learning disabilities. Preventing School Failure, 40(1), 5-10.

Wiederholt, J. L., \& Chamberlain, S. P. (1989). A critical analysis of resource programs. Remedial and Special Education, 10(6), 15-37.

Wiener, J., \& Tardif, C. Y. (2004). Social and emotional functioning of children with learning disabilities: Does special education placement make a difference? Learning Disabilities Research \& Practice, 19(1), 20-32.

Wilczenski, F. (1992). Coming to terms with an identity of "learning disabled" in college. Journal of College Student Psychotherapy, 7(1), 49-61. 
Will, M. (1986). Educating students with learning problems - a shared responsibility. Washington DC: U.S. Department of Education, Office of Special Education and Rehabilitative Services.

Winzer, M. A. (1993). The history of special education: From isolation to integration. Washington, DC: Gallaudet University Press.

Yauman, B. (1980). Placement and self-concept. Learning Disability Quarterly, 3, 30-35.

Yell, M. L., Rogers, D., \& Lodge Rodgers, E. (1998). The legal history of special education: What a long strange trip it's been! Remedial \& Special Education, 19(4), 219-228.

Ysseldyke, J. E., \& Algozzine, B. (1984). Introduction to special education. Boston: Houghton Mifflin.

Zigmond, N., \& Baker, J. M. (1995). Concluding comments: Current and future practices in inclusive schooling. The Journal of Special Education, 29, 245-250.

Zirkel, P. (1996). Inclusion: Return of the pendulum? The Special Educator, 12, 1-5.

Zorfass, J. (1994). An electronic conversation on inclusion. The TAM Newsletter, 9, 4. 


\section{APPENDIX A INTERVIEW AND SURVEY QUESTIONS}

Name Grade Years in Resource Room

1. What is the resource room (Mrs. Mitchell's room)?

2. Why do you think you come to the resource room (Mrs. Mitchell's room)?

3. What are the benefits of Mrs. Mitchell's room? (What do you like about it?)

4. What are the limitations of Mrs. Mitchell's room? (What do you not like about it?)

5. What are some improvements that could be made? Is there anything you would change? Why?

6. Additional comments or questions 


\section{APPENDIX B \\ PARENTAL AND STUDENT CONSENT FORM}

Dear Parent/Guardian,

We are looking forward to another outstanding year at Christian Academy Schools and are pleased that you have allowed us to serve your family this year.

I have been the third grade teacher at Christian Academy Schools for the past six years and am looking forward to another blessed year of teaching. I am currently working toward a Masters of Education from Cedarville University. My final thesis project will be researching student knowledge, perceived benefits and limitations of the resource room and suggestions for improvement.

The resource room, also known as Mrs. Mitchell's room, has profoundly impacted Christian Academy Schools by servicing students that need extra support and academic help. Although numerous researchers have studied resource rooms, we know little about student knowledge and perceptions of resource rooms. What do students think of the resource room? What limitations do they see? What benefits do they see? Do they have suggestions for improvement? The feedback gained will give students a voice and enables to us better service them.

I am requesting permission to interview your child regarding his/her knowledge and perceptions of the resource room. Most of these interviews will be conducted during school hours during free periods as much as possible without interfering with your child's learning. At any time during the study, your child may decide to terminate participation without any negative consequences. The interviews will be taped to allow further processing of the data. All information from the interviews will be kept confidential and names will be changed in any reports. The final report may be viewed at your request. Please sign the permission slip below and return it to the school office by Thursday, November $5^{\text {th }}$. Thank you for partnering with me to give students a voice. I appreciate your cooperation. If you have any further questions, please feel free to contact me at susan_blackford@scesc.k12.oh.us or my thesis advisor, Dr. Shelly Dugle at duglev@cedarville.edu.

Sincerely, Mrs. Susan Blackford

I give permission for my child to participate in an interview regarding his/her knowledge and perceptions of the resource room. I understand that participation can be terminated at any time without negative consequences. I also grant permission for the interview to be taped. I understand that confidentiality will be maintained. 
I do not give permission for my child to participate in an interview regarding his/her knowledge and perceptions of the resource room.

Student's name Date

Parent/Guardian Signature

Student's Signature

If permission is not given please explain why. 


\section{APPENDIX C TEACHER AND ADMINISTRATOR CONSENT FORM}

\section{Dear Teacher,}

I am currently working toward a Masters of Education from Cedarville University. My final thesis project will be researching student knowledge, perceived benefits and limitations of the resource room and suggestions for improvement.

The resource room, also known as Mrs. Mitchell's room, has profoundly impacted Christian Academy Schools by servicing students that need extra support and academic help. Although numerous researchers have studied resource rooms, we know little about student knowledge and perceptions of resource rooms. What do students think of the resource room? What limitations do they see? What benefits do they see? Do they have suggestions for improvement? The feedback gained will give students a voice and enables to us better service them.

I will be interviewing students on their knowledge, perceived benefits and limitations of the resource room and suggestions for improvement. I am requesting your assistance by providing an educator's viewpoint regarding the resource room. At any time during the study, you may decide to terminate participation without any negative consequences. Please complete the survey and turn in your permission slip by Thursday, November $5^{\text {th }}$. Please place the completed survey and permission slip in the envelope in the workroom and check your name off. I will not look inside the envelope until I have received all the surveys. By completing the survey you are granting your consent for me to use your information in my thesis. Your survey will remain confidential and will not be seen by the administration. The final report may be reviewed at your request. I appreciate your cooperation. If you have any further questions, please feel free to contact me at susan_blackford@scesc.k12.oh.us or my thesis advisor, Dr. Shelly Dugle at duglev@cedarville.edu.

Sincerely, Mrs. Susan Blackford 
I desire to participate in this study. I give permission to use my information from the survey in your thesis. I understand that participation can be terminated at any time without negative consequences. I understand that confidentiality will be maintained.

I do not desire to participate in this study. I do not give permission to use my information from the survey in your thesis. I understand that there will not be any negative consequences for not participating.

Teacher's name

Date

Teacher's Signature

If permission is not granted, please explain why. 